\title{
Atelerix algirus, the North African Hedgehog: Suitable Wild Host for Infected Ticks and Fleas and Reservoir of Vector-Borne Pathogens in Tunisia
}

\author{
Ghofrane Balti ${ }^{1}$, Clemence Galon ${ }^{2}$, Moufida Derghal ${ }^{3}$, Hejer Souguir ${ }^{3} \oplus$, Souheila Guerbouj ${ }^{3}$, Adel Rhim ${ }^{1}$, \\ Jomâa Chemkhi $^{3}$, Ikram Guizani ${ }^{3}$, Ali Bouattour ${ }^{1}$, Sara Moutailler ${ }^{2, *(D)}$ and Youmna M'ghirbi ${ }^{1, *(D)}$ \\ 1 Laboratory of Viruses, Vectors and Hosts, LR20IPT02, Institut Pasteur de Tunis, Université Tunis El Manar, 13, \\ Place Pasteur, Tunis 1002, Tunisia; b.ghofraane@gmail.com (G.B.); adel.rhim@yahoo.fr (A.R.); \\ ali.bouattour@pasteur.tn (A.B.) \\ 2 Unité Mixte de Recherche de Biologie Moléculaire et d'Immunologie Parasitaires, Animal Health Laboratory, \\ Agence Nationale de Sécurité Sanitaire de l'Alimentation, de l'Environnement et du Travail, \\ National Veterinary School of Alfort, Paris-Est University, Maisons-Alfort, 94700 Paris, France; \\ clemence.galon@anses.fr \\ 3 Laboratory of Molecular Epidemiology and Experimental Pathology, LR16IPT04, Institut Pasteur de Tunis, \\ Université Tunis El Manar, Tunis 1002, Tunisia; dgl.moufida@gmail.com (M.D.); \\ souguirhejer@gmail.com (H.S.); souheila.guerbouj@gmail.com (S.G.); \\ chemkhijomaa@gmail.com (J.C.); ikram.guizani@pasteur.tn (I.G.) \\ * Correspondence: sara.moutailler@anses.fr (S.M.); youmna.mghirbi@pasteur.tn (Y.M.)
}

Citation: Balti, G.; Galon, C.; Derghal, M.; Souguir, H.; Guerbouj, S.; Rhim, A.; Chemkhi, J.; Guizani, I.; Bouattour, A.; Moutailler, S.; et al. Atelerix algirus, the North African Hedgehog: Suitable Wild Host for Infected Ticks and Fleas and Reservoir of Vector-Borne Pathogens in Tunisia. Pathogens 2021, 10, 953 https://doi.org/10.3390/ pathogens10080953

Academic Editor: Olivier Sparagano

Received: 11 June 2021

Accepted: 6 July 2021

Published: 29 July 2021

Publisher's Note: MDPI stays neutral with regard to jurisdictional claims in published maps and institutional affiliations.

Copyright: (c) 2021 by the authors. Licensee MDPI, Basel, Switzerland. This article is an open access article distributed under the terms and conditions of the Creative Commons Attribution (CC BY) license (https:/ / creativecommons.org/licenses/by/ $4.0 /)$.
Abstract: Small wild mammals are an important element in the emergence and transmission of vectorborne pathogens (VBPs). Among these species, hedgehogs have been found to be a reservoir of VBPs and host of arthropod vectors. Surveillance of VBPs in wildlife and their arthropods are crucial in a one health context. We conducted an exploratory study to screen Atelerix algirus hedgehogs and their infesting ticks and fleas for VBPs using a high throughput microfluidic real-time PCR system. Tested biopsies from hedgehogs were found to be naturally infected by Theileria youngi, Hepatozoon sp., Ehrlichia ewingii, Coxiella burnetii, and Candidatus Ehrlichia shimanensis. Similarly, Haemaphysalis erinacei and Rhipicephalus sanguineus tick species were infected by Ehrlichia ewingii, Rickettsia spp., Rickettsia massiliae, Borrelia sp., Coxiella burnetii, Rickettsia lusitaniae and Anaplasma sp. Archaeopsylla erinacei fleas were infected by Rickettsia asembonensis, Coxiella burnetii, and Rickettsia massiliae. Co-infections by two and three pathogens were detected in hedgehogs and infesting ticks and fleas. The microfluidic real-time PCR system enabled us not only to detect new and unexpected pathogens, but also to identify co-infections in hedgehogs, ticks, and fleas. We suggest that hedgehogs may play a reservoir role for VBPs in Tunisia and contribute to maintaining enzootic pathogen cycles via arthropod vectors.

Keywords: pathogens; hedgehogs; vectors; zoonotic diseases; microfluidic real-time PCR

\section{Introduction}

Wild fauna has always been considered to play a fundamental role in the emergence and re-emergence of zoonotic diseases in nature. In fact, most emerging zoonotic pathogens are of wild animal origin [1]. Major drivers of zoonotic disease emergence and spillover include human activities such as urbanization and landscape modification, which disrupt the ecosystems of wild mammal hosts [2-4]. This is true especially for vector-borne diseases (VBDs) that have multi-element transmission cycles and that could be directly or indirectly affected by ecosystem disruptions [5]. In such transmission cycles, wild mammal hosts play a prominent role in the amplification and/or transmission of pathogens; they are also suitable hosts for hematophagous arthropods [6-8].

VBDs represent a considerable challenge in a one health perspective in view of transmission and pathogen diversity, and human and animal exposure risk and mortality. 
Furthermore, the discovery and emergence of new pathogens, due in most cases to the invasion of new habitats by vector species and wild reservoir hosts, highlight the need for an intensified surveillance and well-developed investigations [9]. Among this wildlife, hedgehogs (Eulipotyphla: Erinaceidae) could play an important role in the emergence of zoonotic vector-borne pathogens. Hedgehogs, small insectivorous wild-living mammals with nocturnal habits, are distributed throughout most of the temperate and tropical areas of Europe, Asia and Africa, and in New Zealand by introduction [10,11]. Different species are reported: Erinaceus europaeus (Linnaeus, 1758) is commonly reported in European countries; however, Atelerix algirus (Lereboullet, 1842) is native to the northern regions of Africa from Morocco to Libya, and to the Balearic and Canary islands [10,12]. In Tunisia, A. algirus has recently been reported to live in sympatry with the desert hedgehog Paraechinus aethiopicus $[10,13]$.

These animals are highly adaptable denizens of urban and suburban areas $[13,14]$. They are commonly infested with different ectoparasites, mainly hard ticks (Ixodidae) and fleas (Siphonaptera) [15-20] of particular medical and veterinary interest. This can increase the risk of direct exposure of humans and companion animals to arthropods [21].

The European hedgehog, Erinaceus europaeus, and its infesting ticks have been found to be infected with Borrelia burgdorferi (s.l.) genospecies [22-24], Anaplasma phagocytophilum [25,26], Rickettsia helvetica [27] and tick-borne encephalitis virus (TBEV) [28]. Moreover, Neoehrlichia mikurensis and Anaplasma phagocytophilum were detected in Northern white-breasted hedgehog (Erinaceus roumanicus) tissue samples in Hungary [29]. Recently, Coxiella burnetii, the causative agent of $\mathrm{Q}$ fever, was detected in Erinaceus amurensis hedgehogs in China [30]. These studies suggest that hedgehogs may serve as reservoir hosts for several zoonotic vector-borne pathogens (VBPs) and could contribute to their enzootic cycles in nature.

In contrast to European hedgehog species, few studies have been performed exploring VBPs that may occur in the North African hedgehog, Atelerix algirus. Investigations conducted in Algeria reported infection of A. algirus with Bartonella tribocorum and B. elizabethae [31]; in addition, Rickettsia felis and Rickettsia massiliae have been detected in fleas and ticks infesting this hedgehog species, respectively [19,32]. Furthermore, A. algirus was proven to be a potential reservoir for Leishmania major and Leishmania infantum in Algeria and Tunisia [33-35].

The implication of hedgehogs in the transmission and maintenance of several emerging etiological agents of public health concern in Tunisia has not been elucidated to date. As a result, using large-scale high-throughput screening, we aimed to explore whether hedgehogs in Tunisia contribute to the enzootic cycle of vector-borne bacteria and protozoa, and to shed more light on the mechanisms of transmission cycles involving hedgehogs, and their infesting tick and flea species. To the best of our knowledge, this is the first large-scale high-throughput screening investigation of vector-borne bacteria and protozoa in Atelerix algirus hedgehogs and their ectoparasites in Tunisia.

\section{Results}

\subsection{Investigated Hedgehogs and Infesting Arthropods}

Based on external morphological criteria, all captured hedgehogs $(n=20)$ were identified as Atelerix algirus (Table 1). A total of 105 tissue samples were obtained after hedgehog dissection (20 spleens, 20 livers, 17 kidney, 18 hearts, 10 lymph nodes, 12 blood and 8 bone marrow fluids). 
Table 1. Studied hedgehogs according to geographical location, sex, and ectoparasite infestation (ticks and fleas).

\begin{tabular}{|c|c|c|c|c|c|c|}
\hline Hedgehog & Region & Locality & $\begin{array}{l}\text { Geographical } \\
\text { Coordinates }\end{array}$ & Sex ${ }^{a}$ & No of Collected Ticks ${ }^{b}$ & No of Collected Fleas ${ }^{b}$ \\
\hline ED1 & Kef & Dahmani & $\begin{array}{l}\text { N: } 35^{\circ} 56^{\prime} 35.606^{\prime \prime} \\
\text { E: } 8^{\circ} 49^{\prime} 50.747^{\prime \prime}\end{array}$ & M & 8 & 20 \\
\hline EZ4 & Kef & Oued Souani & $\begin{array}{l}\mathrm{N}: 36^{\circ} 11^{\prime} 49.6^{\prime \prime} \\
\text { E: } 8^{\circ} 58^{\prime} 33.964^{\prime \prime}\end{array}$ & M & 8 & 3 \\
\hline EB1 & Bizerte & Metline & $\begin{array}{l}\text { N: } 37^{\circ} 14^{\prime} 56.022^{\prime \prime} \\
\text { E: } 10^{\circ} 02^{\prime} 29.616^{\prime \prime}\end{array}$ & $\mathrm{F}$ & 55 & 51 \\
\hline EB2 & Bizerte & El Garia & $\begin{array}{l}\text { N: } 37^{\circ} 13^{\prime} 57.45^{\prime \prime} \\
\text { E: } 10^{\circ} 3^{\prime} 0.029^{\prime \prime}\end{array}$ & $\mathrm{F}$ & 1 & 0 \\
\hline EB3 & Bizerte & Bazina & $\begin{array}{c}\text { N: } 36^{\circ} 57^{\prime} 49.392^{\prime \prime} \\
\text { E: } 9^{\circ} 18^{\prime} 0.158^{\prime \prime}\end{array}$ & F & 3 & 2 \\
\hline EB4 & Bizerte & Bni Atta & $\begin{array}{l}\text { N: } 37^{\circ} 13^{\prime} 55.42^{\prime \prime} \\
\text { E: } 10^{\circ} 5^{\prime} 0.701^{\prime \prime}\end{array}$ & M & 8 & 4 \\
\hline EB5 & Bizerte & Joumine & $\begin{array}{l}\text { N: } 36^{\circ} 55^{\prime} 34.248^{\prime \prime} \\
\text { E: } 9^{\circ} 23^{\prime} 14.744^{\prime \prime}\end{array}$ & $\mathrm{F}$ & 3 & 3 \\
\hline EB6 & Bizerte & El Garia & $\begin{array}{l}\text { N: } 37^{\circ} 13^{\prime} 57.45^{\prime \prime} \\
\text { E: } 10^{\circ} 3^{\prime} 0.029^{\prime \prime}\end{array}$ & M & 7 & 5 \\
\hline EG1 & Kasserine & Bouzguem & $\begin{array}{l}\mathrm{N}: 35^{\circ} 10^{\prime} 03^{\prime \prime} \\
\mathrm{E}: 8^{\circ} 50^{\prime} 11^{\prime \prime}\end{array}$ & M & 17 & 4 \\
\hline EA1 & Kef & Abida & $\begin{array}{l}\text { N: } 35^{\circ} 59.392^{\prime \prime} \\
\text { E: } 8^{\circ} 44^{\prime} 13.574^{\prime \prime}\end{array}$ & $\mathrm{F}$ & $\mathrm{Nd}$ & $\mathrm{Nd}$ \\
\hline EA2 & Kef & Abida & $\begin{array}{c}\text { N: } 35^{\circ} 59.392^{\prime \prime} \\
\text { E: } 8^{\circ} 44^{\prime} 13.574^{\prime \prime}\end{array}$ & $\mathrm{F}$ & $\mathrm{Nd}$ & $\mathrm{Nd}$ \\
\hline EA3 & Kef & Abida & $\begin{array}{c}\text { N: } 35^{\circ} 59.392^{\prime \prime} \\
\text { E: } 8^{\circ} 44^{\prime} 13.574^{\prime \prime}\end{array}$ & $\mathrm{F}$ & $\mathrm{Nd}$ & $\mathrm{Nd}$ \\
\hline EA4 & Kef & Abida & $\begin{array}{c}\text { N: } 35^{\circ} 59.392^{\prime \prime} \\
\text { E: } 8^{\circ} 44^{\prime} 13.574^{\prime \prime}\end{array}$ & F & $\mathrm{Nd}$ & $\mathrm{Nd}$ \\
\hline EA5 & Kef & Abida & $\begin{array}{l}\text { N: } 35^{\circ} 59.392^{\prime \prime} \\
\text { E: } 8^{\circ} 44^{\prime} 13.574^{\prime \prime}\end{array}$ & M & $\mathrm{Nd}$ & $\mathrm{Nd}$ \\
\hline EA6 & Kef & Abida & $\begin{array}{c}\text { N: } 35^{\circ} 59.392^{\prime \prime} \\
\text { E: } 8^{\circ} 44^{\prime} 13.574^{\prime \prime}\end{array}$ & M & $\mathrm{Nd}$ & $\mathrm{Nd}$ \\
\hline EA7 & Kef & Abida & $\begin{array}{l}\mathrm{N}: 35^{\circ} 59.392^{\prime \prime} \\
\text { E: } 8^{\circ} 44^{\prime} 13.574^{\prime \prime}\end{array}$ & M & $\mathrm{Nd}$ & $\mathrm{Nd}$ \\
\hline EZ1 & Kef & Zaafran & $\begin{array}{c}\text { N: } 33^{\circ} 26^{\prime} 39.271^{\prime \prime} \\
\text { E: } 8^{\circ} 55^{\prime} 18.39^{\prime \prime}\end{array}$ & $\mathrm{F}$ & $\mathrm{Nd}$ & $\mathrm{Nd}$ \\
\hline EZ2 & Kef & Zaafran & $\begin{array}{c}\text { N: } 33^{\circ} 26^{\prime} 39.271^{\prime \prime} \\
\text { E: } 8^{\circ} 55^{\prime} 18.39^{\prime \prime}\end{array}$ & M & $\mathrm{Nd}$ & $\mathrm{Nd}$ \\
\hline EZ3 & Kef & Zaafran & $\begin{array}{c}\text { N: } 33^{\circ} 26^{\prime} 39.271^{\prime \prime} \\
\text { E: } 8^{\circ} 55^{\prime} 18.39^{\prime \prime}\end{array}$ & $\mathrm{F}$ & $\mathrm{Nd}$ & $\mathrm{Nd}$ \\
\hline ES1 & Kef & Kalaat Senan & $\begin{array}{c}\text { N: } 35^{\circ} 45^{\prime} 20.254^{\prime \prime} \\
\text { E: } 8^{\circ} 21^{\prime} 9.562^{\prime \prime}\end{array}$ & M & 0 & 0 \\
\hline
\end{tabular}

A total of 110 ticks and 92 fleas were collected from nine hedgehogs (ED1, EZ4, EB1EB6, and EG1). The remaining hedgehogs (EA1-EA7; EZ1-EZ3) were not examined for the presence of ectoparasites (Table 1$)$. The majority of ticks were semi-engorged and identified as Haemaphysalis erinacei $(n=92)$, followed by Rhipicephalus sanguineus $(n=15)$, and Hyalomma aegyptium $(n=1)$; only two Ixodes spp. were fully engorged. Moreover, the Archaeopsylla erinacei flea was the most common species collected from hedgehogs $(n=91)$, in addition to one specimen of Ctenocephalides felis.

Among the 10 hedgehogs examined for arthropod infestation, nine were infested with ticks and fleas. Among them, only one was infested solely by ticks. The number of ticks and fleas infesting hedgehogs ranged from 0 to 55 (mean $=11 ; 10 \%$ [95\% Confidence interval: 8.2-13.8]) and 0 to 51 (mean $=9.2 ; 10 \%$ [95\% Confidence interval: $6.15-12.3]$ ), respectively. 
Interestingly, one hedgehog (EB1) captured from the Bizerte region was heavily infested and carried almost half of the total collected ticks $(55 / 110 ; 50 \%)$ and fleas $(51 / 92 ; 55.4 \%)$ (Figure 1).

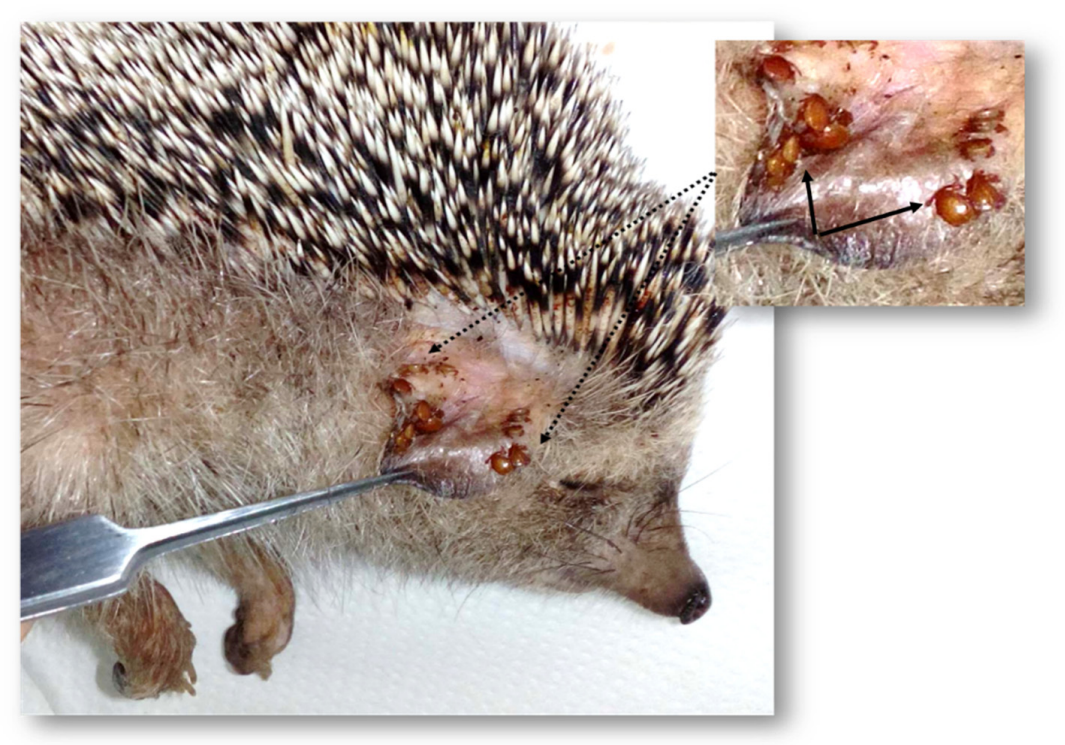

Figure 1. Photo of a hedgehog's ear heavily infested by Haemaphysalis erinacei ticks. Full arrows shows higher magnification of the tick-infested region.

\subsection{Vector-Borne Pathogen Detection in Hedgehog Biopsies and Infesting Arthropods}

A total of 105 biopsies sampled on 20 Atelerix algirus hedgehogs, 110 ticks, and 92 fleas were screened individually for the presence of vector-borne bacteria (Rickettsia, Anaplasma, Ehrlichia, Bartonella, Borrelia, Coxiella, and Francisella) and protozoa (Babesia, Theileria, and Hepatozoon) using microfluidic real-time PCR on the BioMark ${ }^{\mathrm{TM}}$ system. The number of positive samples revealed by microfluidic real-time PCR and the corresponding infection rates (IRs) are summarized in Table 2.

Table 2. Infection rates in hedgehogs, ticks, and fleas using microfluidic real-time PCR.

\begin{tabular}{|c|c|c|c|c|c|c|c|}
\hline \multirow[t]{2}{*}{ Pathogen } & \multirow[t]{2}{*}{$\begin{array}{c}\text { Hedgehog IR } \\
\text { (Positive Samples/Total }^{\text {Tested Samples) }}{ }^{\mathrm{a}}\end{array}$} & \multicolumn{4}{|c|}{$\begin{array}{c}\text { Tick IR } \\
\text { (Positive Samples/Total Tested Samples) }^{b}\end{array}$} & \multicolumn{2}{|c|}{$\begin{array}{c}\text { Flea IR } \\
\text { (Positive Samples/Total Tested } \\
\text { Samples) }\end{array}$} \\
\hline & & $\begin{array}{l}\text { Hae. } \\
\text { erinacei }\end{array}$ & Rh. sanguineus & Ixodes spp. & $\begin{array}{c}\text { Hy. } \\
\text { aegyptium }\end{array}$ & $\begin{array}{l}\text { Archaeopsylla } \\
\text { erinacei }\end{array}$ & $\begin{array}{l}\text { Ctenocephalides } \\
\text { felis }\end{array}$ \\
\hline Ehrlichia spp. & $45 \%(9 / 20)$ & $26 \%(24 / 92)$ & 0 & 0 & 0 & 0 & 0 \\
\hline Ehrlichia ewingii & $5 \%(1 / 20)$ & $3.3 \%(3 / 92)$ & 0 & 0 & 0 & 0 & 0 \\
\hline $\begin{array}{l}\text { Candidatus E. } \\
\text { shimanensis }\end{array}$ & $10 \%(2 / 20)$ & 0 & 0 & 0 & 0 & 0 & 0 \\
\hline Coxiella burnetii & $10 \%(2 / 20)$ & $\begin{array}{c}80.4 \% \\
(74 / 92)\end{array}$ & $86.6 \%(13 / 15)$ & $50 \%(1 / 2)$ & $100 \%(1 / 1)$ & $34 \%(31 / 91)$ & $100 \%(1 / 1)$ \\
\hline Rickettsia spp. & $10 \%(2 / 20)$ & $\begin{array}{c}40.2 \% \\
(37 / 92)\end{array}$ & $86.6 \%(13 / 15)$ & $50 \%(1 / 2)$ & 0 & $82.4 \%(75 / 91)$ & $100 \%(1 / 1)$ \\
\hline Rickettsia massiliae & 0 & 0 & $53.3 \%(8 / 15)$ & 0 & 0 & $1.1 \%(1 / 91)$ & 0 \\
\hline Rickettsia lusitaniae & 0 & 0 & $6.7 \%(1 / 15)$ & 0 & 0 & 0 & 0 \\
\hline $\begin{array}{c}\text { Rickettsia } \\
\text { asembonensis }\end{array}$ & 0 & 0 & 0 & 0 & 0 & $78 \%(71 / 91)$ & 0 \\
\hline Bartonella spp. & 0 & $3.3 \%(3 / 92)$ & $6.7 \%(1 / 15)$ & 0 & 0 & $2.2 \%(2 / 91)$ & 0 \\
\hline Theileria youngi & $40 \%(8 / 20)$ & 0 & 0 & 0 & 0 & 0 & 0 \\
\hline Hepatozoon sp. & $5 \%(1 / 20)$ & 0 & 0 & 0 & 0 & 0 & 0 \\
\hline Borrelia sp. & 0 & 0 & $6.7 \%(1 / 15)$ & 0 & 0 & 0 & 0 \\
\hline Anaplasma sp. & 0 & 0 & $6.7 \%(1 / 15)$ & 0 & 0 & 0 & 0 \\
\hline
\end{tabular}

a IR: infection rate; ${ }^{\mathrm{b}}$ Hae: Haemaphysalis; Rh: Rhipicephalus; Hy: Hyalomma. 
To confirm the results obtained by the microfluidic real-time PCR system, conventional PCRs or nested PCRs followed by sequencing were performed on the positive samples. Similarities of the obtained sequences with the available reference sequences in GenBank (NCBI) are presented in Table 3.

Table 3. Microfluidic real-time PCR results confirmed by sequencing of conventional PCR and nested PCR amplification products.

\begin{tabular}{|c|c|c|c|c|c|}
\hline $\begin{array}{c}\text { Pathogen Identification } \\
\text { by Microfluidic } \\
\text { Real-Time PCR }\end{array}$ & Host $^{a}$ & Similarity $\%$ & $\begin{array}{c}\text { Accession } \\
\text { Number of the } \\
\text { Reference Sequences }\end{array}$ & $\begin{array}{l}\text { Pathogen Identification } \\
\text { by Sequencing } \\
\text { (Targeted Gene) }\end{array}$ & $\begin{array}{l}\text { Accession } \\
\text { Number }\end{array}$ \\
\hline Anaplasma spp. & Rh. sanguineus & 99.7 & KJ410249 & $\begin{array}{c}\text { Anaplasma sp. } \\
\text { (16S rRNA) }\end{array}$ & MW508491 \\
\hline Anaplasma spp. & Hae. Erinacei & 99.8 & MN148616 & $\begin{array}{c}\text { E. ewingii } \\
\text { (16S rRNA) }\end{array}$ & MW508469 \\
\hline Ehrlichia spp. & $\begin{array}{l}\text { Hae. erinacei } \\
\text { Atelerix algirus }\end{array}$ & $99.8-100$ & MN148616 & $\begin{array}{c}\text { E. ewingii } \\
\text { (16S rRNA) }\end{array}$ & $\begin{array}{l}\text { MW508471 } \\
\text { MW508473 }\end{array}$ \\
\hline Ehrlichia spp. & Atelerix algirus & 99.3 & AB074459 & $\begin{array}{l}\text { Ca. E. shimenensis } \\
\text { (16S rRNA) }\end{array}$ & $\begin{array}{c}\text { MW508474MW } \\
\text { 508475MW508468 }\end{array}$ \\
\hline Rickettsia spp. & A. erinacei & 100 & $\begin{array}{l}\text { MN186290 } \\
\text { MK923741 }\end{array}$ & $\begin{array}{l}\text { R. asembonensis } \\
\text { (gltA) }\end{array}$ & $\begin{array}{l}\text { MW508476- } \\
\text { MW508479 }\end{array}$ \\
\hline Rickettsia spp. & Rh. sanguineus & 100 & MK761227 & $\begin{array}{l}\text { R. Iusitaniae } \\
\text { (gltA) }\end{array}$ & MW508481 \\
\hline Rickettsia spp. & A. erinacei & 99.3 & AF123714 & $\begin{array}{l}\text { R. massiliae } \\
\quad(\mathrm{ompB})\end{array}$ & MW508483 \\
\hline Rickettsia massiliae & Rh. sanguineus & 100 & DQ503428 & $\begin{array}{l}\text { R. massiliae } \\
\quad(\mathrm{ompB})\end{array}$ & $\begin{array}{l}\text { MW508482- } \\
\text { MW508489 }\end{array}$ \\
\hline Theileria spp. & Atelerix algirus & 99 & AF245279 & $\begin{array}{c}\text { T. youngi } \\
\text { (18S rRNA) }\end{array}$ & $\begin{array}{l}\text { MW508493- } \\
\text { MW508496 }\end{array}$ \\
\hline Hepatozoon spp. & Atelerix algirus & 100 & KU680466 & $\begin{array}{l}\text { Hepatozoon sp. } \\
\text { (18S rRNA) }\end{array}$ & MW508490 \\
\hline Coxiella burnetii & $\begin{array}{c}\text { Atelerix algirus } \\
\text { A. erinacei } \\
\text { Hae. erinacei }\end{array}$ & 100 & $\begin{array}{c}\text { MN540441 } \\
\text { LC46497 }\end{array}$ & $\begin{array}{c}\text { C. burnetii } \\
\text { (16S rRNA) }\end{array}$ & $\begin{array}{l}\text { MW508460- } \\
\text { MW508464 }\end{array}$ \\
\hline Borrelia sp. & Rh. sanguineus & 99.7 & MN958351 & $\begin{array}{l}\text { Borrelia sp. } \\
\quad(\mathrm{flaB})\end{array}$ & MW508492 \\
\hline
\end{tabular}

${ }^{a}$ Rh: Rhipicephalus; Hae: Haemaphysalis; A: Archaeopsylla; ${ }^{\mathrm{b}}$ E: Ehrlichia; Ca. E: Candidatus Ehrlichia; R: Rickettsia; T: Theileria; C: Coxiella.

\subsubsection{Vector-Borne Pathogen Detection in Atelerix Algirus Hedgehogs}

Using the microfluidic real-time PCR system, nine A. algirus $(9 / 20 ; 45 \%)$ were positive for Ehrlichia spp. (Table 2). Among 105 analyzed biopsies, 14 were positive for Ehrlichia spp. (13.3\%). Among them, one had three infected organs (heart, spleen, and liver); and three hedgehogs had two infected organs: blood and either liver, heart or bone-marrow fluid. The remaining A. algirus (five out of nine) showed infection in either blood, kidney, spleen or bone marrow fluid.

To further confirm the occurrence of Ehrlichia species in hedgehog biopsies, we were able to obtain four sequences by amplifying a 16S rRNA gene fragment by nested PCR (Table 3). We revealed two different genotypes: (i) three sequences obtained from the liver, heart, and kidney (accession numbers MW508468, MW508474, and MW508475) displayed 99.15-99.33\% identity with Candidatus Ehrlichia shimanensis (accession number AB074459), (ii) one sequence obtained from a blood sample (accession number MW508473) showed 99.7\% identity with Ehrlichia ewingii (accession number MN148616). The E. ewingii and Candidatus Ehrlichia shimanensis sequences identified in this study were in the same cluster as several E. ewingii and Candidatus Ehrlichia shimanensis sequences available in GenBank, respectively (Figure 2). 


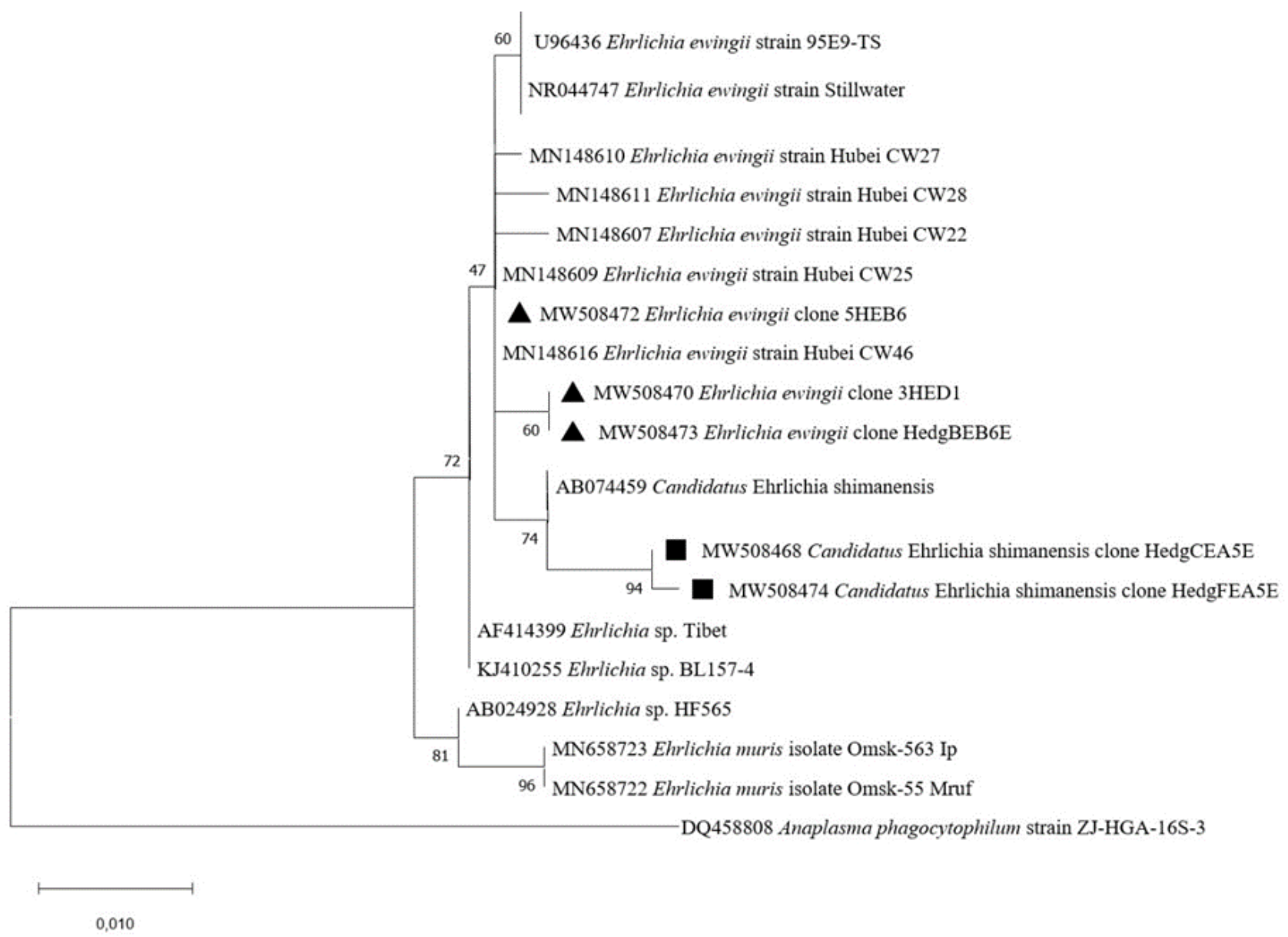

Figure 2. Phylogenetic analysis of 16S rRNA sequences of Ehrlichia spp. Phylogenetic analysis of 16S rRNA sequences of Ehrlichia spp. using the maximum likelihood method based on the General Time Reversible model. In the phylogenetic tree, GenBank sequences, species designations and strain names are given. The sequences investigated in the present study are marked with a black triangle (E. ewingii) and black square ( $\mathrm{Ca}$. E. shimenensis). The tree with the highest log likelihood (-952.31) is shown. The percentage of trees in which the associated taxa clustered together is shown next to the branches (bootstrap values). A discrete Gamma distribution was used to model evolutionary rate differences among sites $(5$ categories $(+G$, parameter $=200.0000)$ ). The rate variation model allowed for some sites to be evolutionarily invariable $([+I], 37.52 \%$ sites). The tree is drawn to scale, with branch lengths measured in the number of substitutions per site. This analysis involved 22 nucleotide sequences. There were a total of 510 positions in the final dataset.

Theileria spp. DNA was detected in eight $A$. algirus (8/20, 40\%). Fourteen of $105(13.3 \%)$ biopsies from these hedgehogs were found to be Theileria-positive. Among these hedgehogs, three had two infected organs: liver and either heart, kidney or blood; while one specimen had an infection in three different samples (liver, blood, and lymph node). The remaining hedgehogs $(n=4)$ were infected in solely one organ: in the blood $(n=3)$, and in the heart $(n=1)$. Using microfluidic real-time PCRs, no signal was obtained for the two targeted Theileria species (T. velifera and T. mutans) suggesting infection by another Theileria species. The partial sequences of the 18S rRNA gene obtained (accession numbers MW508493, MW508494, and MW508496) were 98.9-99.7\% similar to Theileria youngi (accession number AF245279) (Tables 2 and 3). Theileria youngi sequences obtained in this study are within the same cluster as the reference sequence of $T$. youngi in GenBank.

Furthermore, the liver of one hedgehog $(1 / 20,5 \%)$ was positive for Hepatozoon spp. (Table 2). Amplification of $18 \mathrm{~S}$ rRNA using nested PCR and sequencing of the PCR product revealed a sequence (accession number MW508490) 100\% identical to uncharacterized Hepatozoon species (accession number KU680466) (Table 2). Our sequence clustered with several uncharacterized Hepatozoon sp. (Figure 3). 


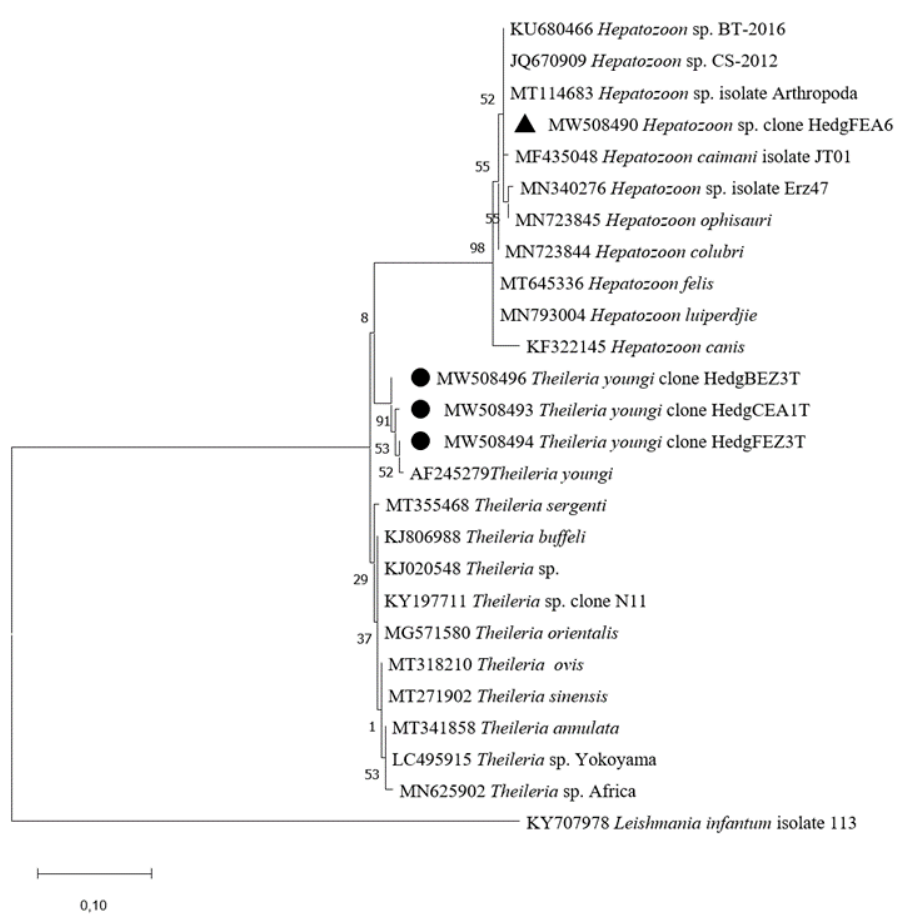

Figure 3. Phylogenetic analysis of $18 \mathrm{~S}$ rRNA sequences of Theileria spp. and Hepatozoon spp. Phylogenetic analysis of $18 \mathrm{~S}$ rRNA sequences of Theileria spp. and Hepatozoon spp. using the Maximum Likelihood method based on the General Time Reversible model. In the phylogenetic tree, GenBank sequences, species designations and strain names are given. The sequences investigated in the present study is marked with a black circle (Theileria youngi) and black triangle (Hepatozoon sp.). The tree with the highest log likelihood $(-561.93)$ is shown. The percentage of trees in which the associated taxa clustered together is shown next to the branches (bootstrap values). A discrete Gamma distribution was used to model evolutionary rate differences among sites ( 5 categories $(+G$, parameter $=2.0666)$ ). The tree is drawn to scale, with branch lengths measured in the number of substitutions per site. This analysis involved 26 nucleotide sequences. All positions containing gaps and missing data were eliminated (complete deletion option). There were a total of 250 positions in the final dataset.

Coxiella burnetii DNA was detected in two A. algirus hedgehogs (2/20, 10\%, Table 2): one hedgehog was infected in three different biopsies (spleen, liver, and lymph node), while the other hedgehog had a blood infection. To confirm the microfluidic real-time PCR results, we amplified and sequenced a 16S rRNA gene fragment. Only one sequence was successful (accession number MW508461) which showed 100\% identity (Table 3) with the Coxiella burnetii strain SFA062 from humans (accession number MN540441).

Lastly, two hedgehogs $(2 / 20,10 \%)$, were positive for Rickettsia spp. (Table 2). One was infected in three different biopsies (spleen, heart, and liver), while the other was infected in the liver. Unfortunately, neither conventional PCR targeting gltA nor nested PCR targeting ompB succeeded in confirming the microfluidic real-time PCR results.

\subsubsection{Vector-Borne Pathogen Detection in Ticks}

The most common pathogen detected in Haemaphysalis erinacei and Rhipicephalus sanguineus ticks collected from hedgehogs was Coxiella burnetii, with an infection rate reaching $80.4 \%(74 / 92)$ and 86.6\% (13/15), respectively (Table 2). In addition, C. burnetii was also detected in one of the two fully engorged Ixodes spp. and in the only Hyalomma aegyptium tested. The presence of $C$. burnetii was confirmed by nested PCR targeting the 16S rRNA gene in six randomly chosen positive Hae. erinacei ticks. Obtained sequences (accession numbers MW508462-MW508467) were 99-100\% similar to C. burnetii strain CB-30 and C. burnetii strain SFA062 (accession numbers LC46497 and MN540441) (Table 3). Unfortunately, none of the randomly chosen $R h$. sanguineus Coxiella burnetii-positive 
samples $(n=3)$ were successfully amplified by nested PCR to confirm corresponding microfluidic results.

Rickettsia spp. were detected in $40.2 \%$ of tested Hae. erinacei ticks (37/92) and in $86.6 \%$ of $R$ h. sanguineus (13/15) (Table 2$)$. We did not succeed in amplifying the gltA or ompB genes to further identify the Rickettsia species in Hae. erinacei by targeted PCR. However, 8 of 15 Rh. sanguineus ticks were found to be infected by Rickettsia massiliae (Table 2). For confirmation, initial attempts to amplify the gltA gene led to successful amplification of 2/8 Rickettsia DNAs (Table 3). One of the sequences (accession number MW508482) showed $100 \%$ identity with $R$. massiliae (accession number DQ503428). The second gltA sequence (accession number MW508481) showed 100\% identity with $R$. lusitaniae (accession number KC428021). To further confirm the results of the remaining six positive Rh. sanguineus, we targeted the ompB gene. Corresponding sequences (accession numbers MW508484MW508489) displayed 99-100\% identity with R. massiliae (accession number MK761227) (Table 3). Rickettsia massiliae sequences obtained in this study clustered with GenBank published $R$. massiliae as shown in the phylogenetic tree (Figure 4). Likewise, the $R$. lusitaniae sequence found in our samples formed a cluster with the deposited $R$. lusitaniae ones (Figure 5).

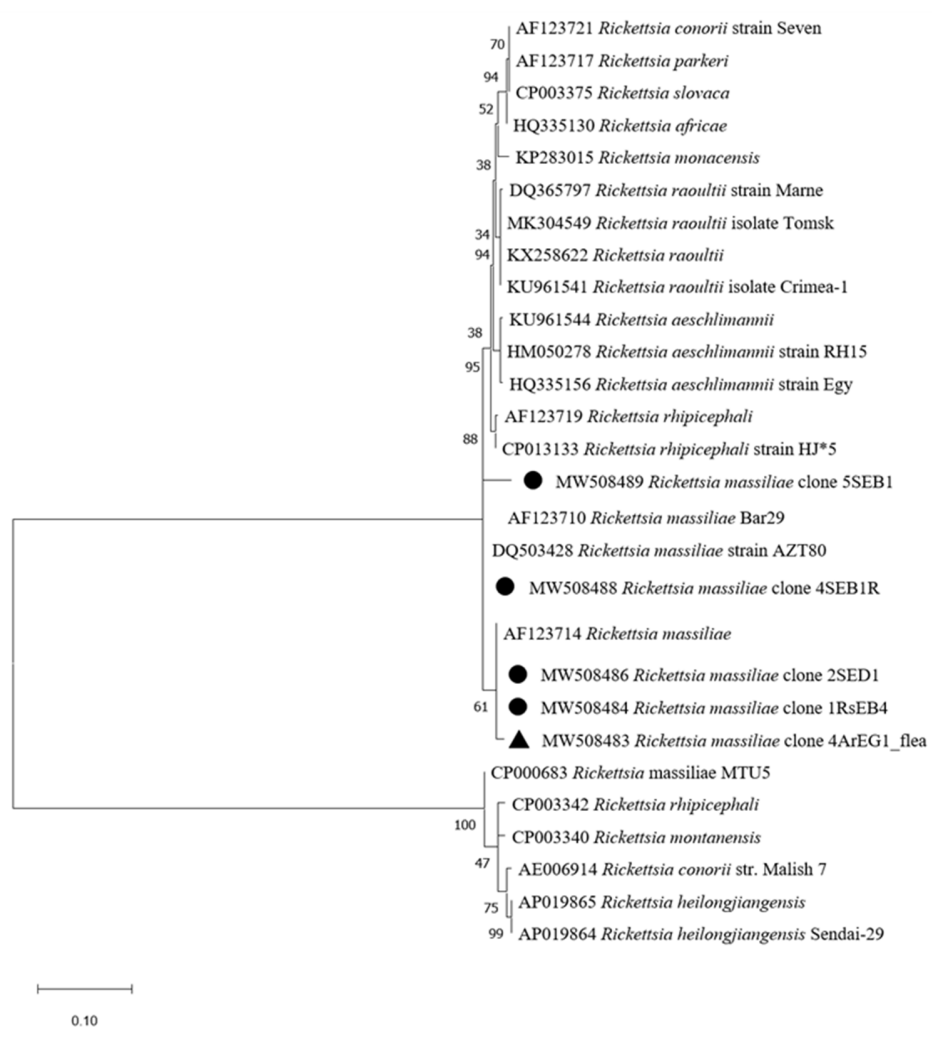

Figure 4. Phylogenetic analysis of ompB sequences of Rickettsia spp. Phylogenetic analysis of ompB sequences of Rickettsia spp using the maximum likelihood method based on the Tamura-Nei model. In the phylogenetic tree, GenBank sequences, species designations and strain names are given. The sequences investigated in the present study are marked with a black circle for the $R$. massiliae sequence recovered from Rhipicephalus sanguineus ticks and a black triangle for $R$. massiliae recovered from Achaeopsylla erinacei fleas. The tree with the highest log likelihood $(-1768.76)$ is shown. The percentage of trees in which the associated taxa clustered together is shown next to the branches (bootstrap values). The rate variation model allowed for some sites to be evolutionarily invariable $([+I], 16.94 \%$ sites). The tree is drawn to scale, with branch lengths measured in the number of substitutions per site. This analysis involved 28 nucleotide sequences. There were a total of 662 positions in the final dataset. 


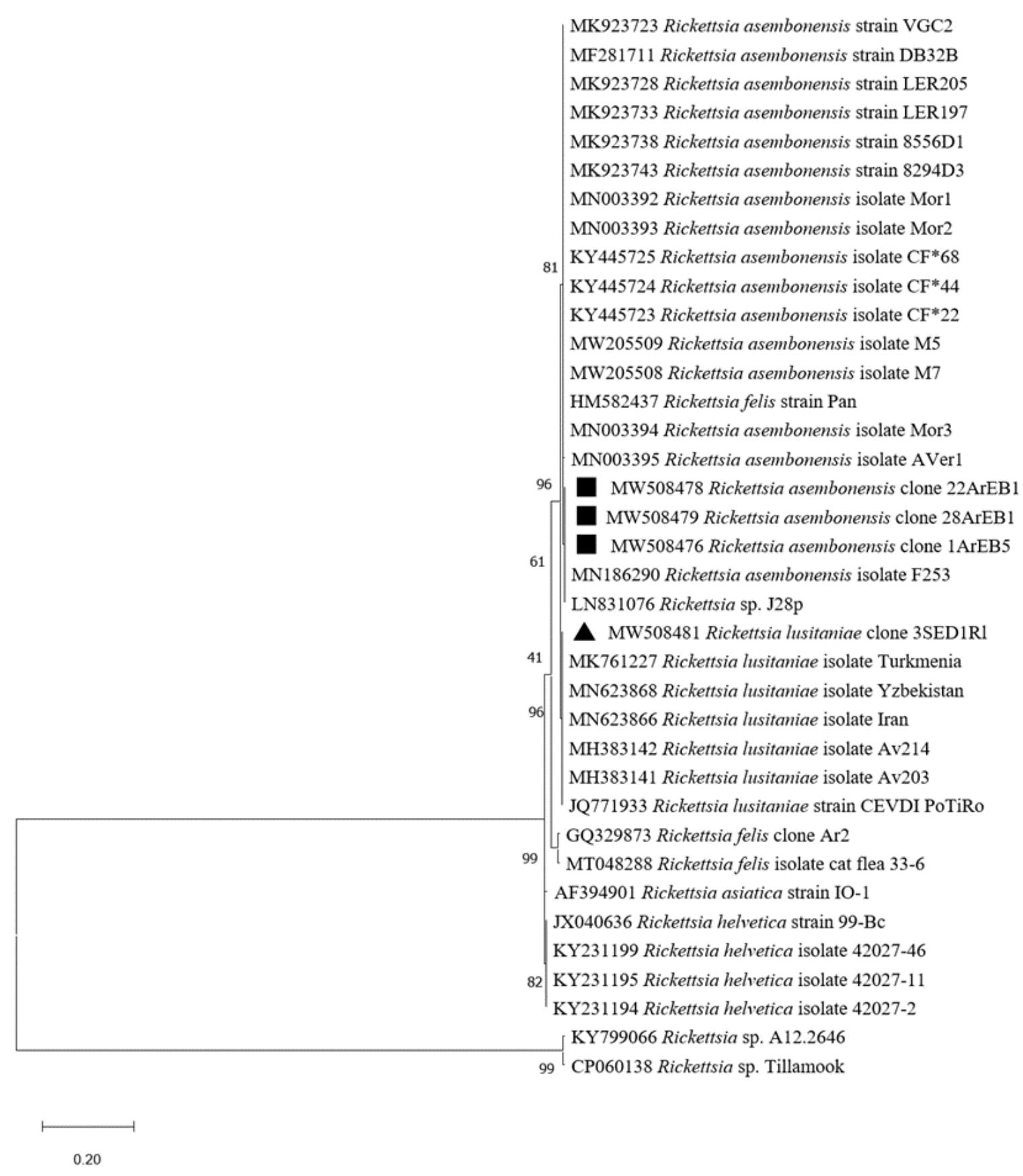

Figure 5. Phylogenetic analysis of gltA sequences of Rickettsia spp. Phylogenetic analysis of gltA sequences of Rickettsia spp. using the maximum likelihood method based on the Kimura 2-parameter model. In the phylogenetic tree, GenBank sequences, species designations and strain names are given. The sequences investigated in the present study is marked with a black square (Rickettsia asembonensis) and black triangle (Rickettsia lusitaniae). The tree with the highest log likelihood $(-1134.16)$ is shown. The percentage of trees in which the associated taxa clustered together is shown next to the branches (bootstrap values). The rate variation model allowed for some sites to be evolutionarily invariable $([+I], 32.20 \%$ sites). The tree is drawn to scale, with branch lengths measured in the number of substitutions per site. This analysis involved 37 nucleotide sequences. There were a total of 410 positions in the final dataset.

Ehrlichia spp. was detected in $26 \%$ of tested Hae. erinacei (24/92), while no Rh. sanguineus were positive (Table 2). To confirm this result and to identify Ehrlichia species, we successfully amplified Ehrlichia DNA in two Hae. erinacei by conventional PCR targeting the 16S rRNA gene (Table 3). Sequences (accession numbers MW508471-MW508472) showed $99.8 \%$ and 100\% identity with Ehrlichia ewingii strain Hubei CW46 (accession 
number MN148616) (Table 2). Our Ehrlichia ewingii sequences clustered within several E. ewingii sequences deposited in GenBank (Figure 2).

Moreover, one Hae. erinacei and one Rh. sanguineus were found to be infected by Anaplasma spp. (Table 2). This result was confirmed by conventional PCR targeting the $16 S$ rRNA gene and the corresponding sequence obtained from $R h$. sanguineus (accession number MW508491) showed 99.7\% identity with an uncharacterized Anaplasma sp. BL102-7 (accession number KJ410249). Likewise, the sequence obtained from Hae. erinacei (accession number MW508469) showed 99.7\% identity with Ehrlichia ewingii strain Hubei CW46 (accession number MN148616) (Table 3). Anaplasma spp. identified in this study clustered with A. phagocytophilum, Candidatus Anaplasma boleense, and several uncharacterized Anaplasma species (Figure 6).

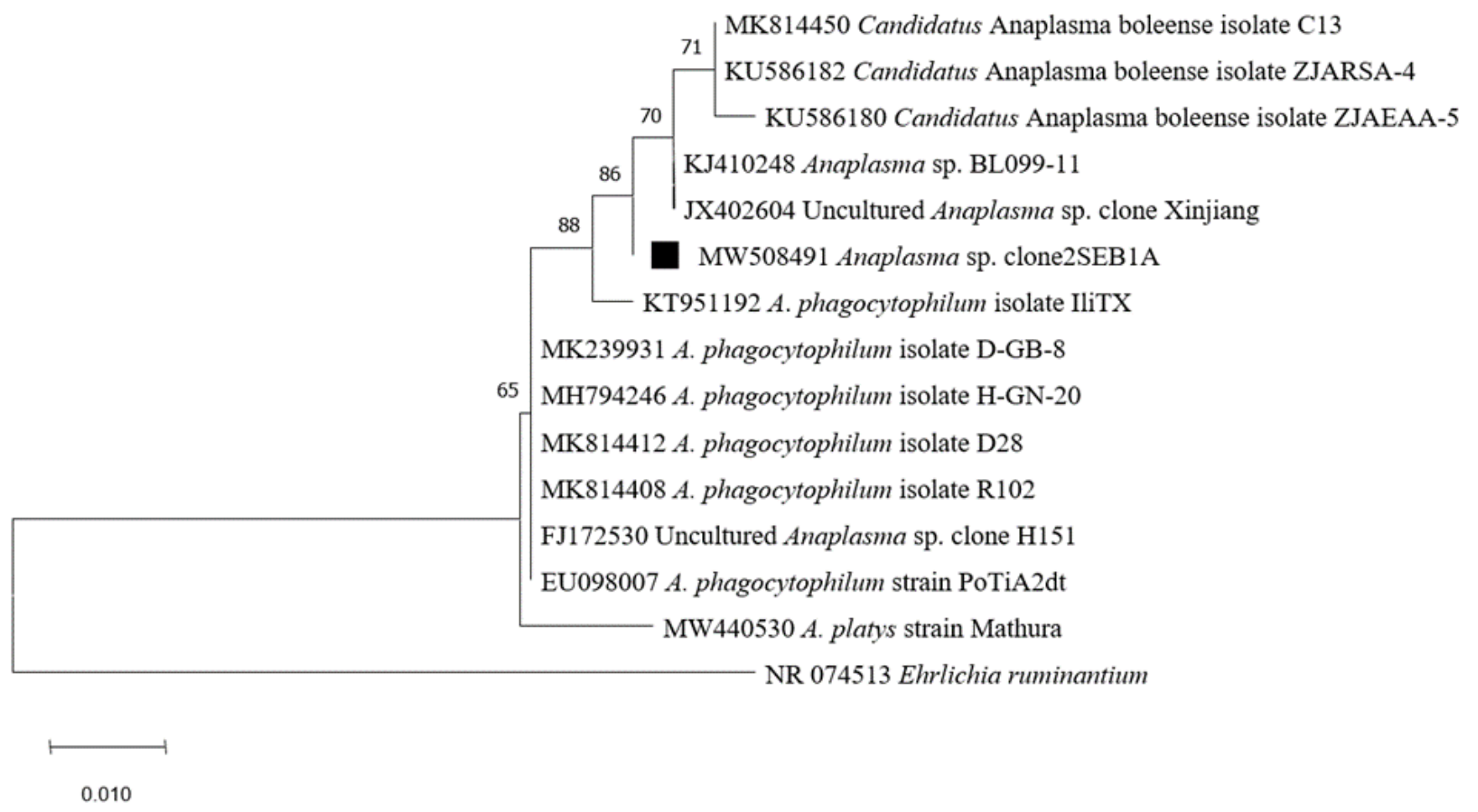

Figure 6. Phylogenetic analysis of 16S rRNA sequences of Anaplasma spp. using the maximum likelihood method based on the General Time Reversible model. In the phylogenetic tree, GenBank sequences, species designations and strain names are given. The sequence investigated in the present study is marked with a black square. The tree with the highest log likelihood $(-851.75)$ is shown. The percentage of trees in which the associated taxa clustered together is shown next to the branches (bootstrap values). The rate variation model allowed for some sites to be evolutionarily invariable $([+I], 45.53 \%$ sites). The tree is drawn to scale, with branch lengths measured in the number of substitutions per site. This analysis involved 15 nucleotide sequences. There were a total of 459 positions in the final dataset.

One Rh. sanguineus was positive for Borrelia spp. but not Borrelia burgdorferi s. 1. species (the Lyme disease agent), nor the Borrelia relapsing fever group primers/probes sets (Table 2). For confirmation, nested PCR targeting the flaB gene was performed and followed by PCR products sequencing. The sequence (accession number MW508492) obtained from this tick was $99.70 \%$ similar to Borrelia sp. clone Ir-Maz190 (accession number MN958351) (Table 3). Phylogenetic analysis showed that Borrelia sp. obtained in this study formed a cluster with some Borrelia species belonging to the relapsing fever group, such as Borrelia lonestari, B. theileri, and uncharacterized Borrelia species (Figure 7). 


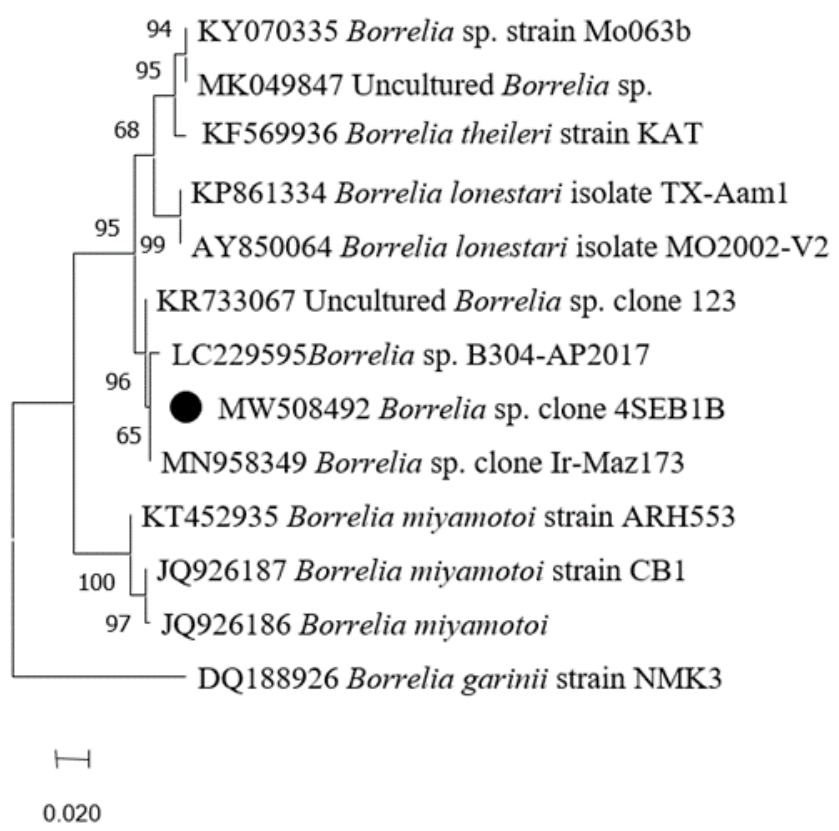

Figure 7. Phylogenetic analysis of flaB sequences of Borrelia spp. Phylogenetic analysis of flaB sequences of Borrelia spp. using the maximum likelihood method based on the General Time Reversible model. In the phylogenetic tree, GenBank sequences, species designations and strain names are given. The sequence investigated in the present study is marked with a black circle. The tree with the highest log likelihood $(-679.69)$ is shown. The percentage of trees in which the associated taxa clustered together is shown next to the branches (bootstrap values). The rate variation model allowed for some sites to be evolutionarily invariable $([+I], 40.19 \%$ sites). The tree is drawn to scale, with branch lengths measured in the number of substitutions per site. This analysis involved 12 nucleotide sequences. There were a total of 265 positions in the final dataset.

Three Hae. erinacei $(3.3 \%, 3 / 92)$ and one Rh. sanguineus $(6.7 \%, 1 / 15)$ (Table 2$)$ were positive for Bartonella spp. Unfortunately, sequencing attempts of the confirmatory PCR products failed.

\subsubsection{Vector-Borne Pathogen Detection in Fleas}

Rickettsia spp. DNA was detected in $82.4 \%$ of Archaeopsylla erinacei (75/91) and in one Ctenocephalides felis $(1 / 1)$ (Table 2). However, none of the targeted Rickettsia species of the BioMark $^{\mathrm{TM}}$ system gave a positive signal, suggesting the presence of unexpected Rickettsia species in the tested hedgehog fleas. To identify the Rickettsia species, we amplified the gltA and ompB genes by nested PCR, followed by sequencing. Four identical gltA sequences (accession numbers MW508476-MW508479) obtained from four Archaeopsylla erinacei were 100\% identical to Rickettsia asembonensis (accession number MN186290) (Table 3). Furthermore, the two partial sequences of the ompB gene fragment from two $A$. erinacei, which infested two different hedgehogs, were 100\% similar (accession number MW508480) to $R$. asembonensis (accession number MK923741) and 99.3\% to R. massiliae (accession number AF123714), respectively. The phylogenetic tree of $R$. asembonensis and $R$. massiliae sequences in this study showed that the sequences were in the same cluster with corresponding reference sequences (Figures 4 and 5 ). The $R$. massiliae sequence amplified in fleas was identical to $R$. massiliae identified in ticks.

Coxiella burnetii DNA was directly detected by the BioMark ${ }^{\mathrm{TM}}$ system in $34.1 \%$ of $A$. erinacei $(31 / 91)$ and one $C$. felis $(1 / 1)$ (Table 2$)$. Nested PCR targeting the $16 \mathrm{~S}$ rRNA gene followed by sequencing of one randomly chosen $A$. erinacei confirmed the microfluidic real-time PCR results. The corresponding sequence (accession number MW508460) was similar to C. burnetii strain SFA062 (accession number MN540441) (Table 2). 
Two A. erinacei fleas $(2.2 \%, 2 / 91)$ were positive for Bartonella spp. by microfluidicreal-time PCR. Unfortunately, conventional PCR targeting either gltA or ITS followed by sequencing did not succeed in confirming the microfluidic PCR results.

\subsubsection{Co-Infection in Hedgehogs, Ticks and Fleas}

Among the 20 tested Atelerix algirus, seven (7/20,35\%) revealed co-infection by at least two pathogens. Double infections were observed in four hedgehogs $(20 \%)$, including infection by Theileria youngi and Ehrlichia spp., while one subject was co-infected by Rickettsia spp. and Hepatozoon sp. Interestingly, a triple infection with C. burnetii, T. youngi, and Ehrlichia spp. was observed in two hedgehogs (10\%).

Additionally, co-infections were revealed in Haemaphysalis erinacei and in Rhipicephalus sanguineus ticks. Almost $45.6 \%$ of tested Hae. erinacei (42/92) and $80 \%$ of Rh. sanguineus $(12 / 15)$ were naturally infected by at least two pathogens. In addition, $21 \%$ of Hae. erinacei (19/92) were co-infected by three pathogens: 18 Hae. erinacei were co-infected by C. burnetii, Rickettsia spp., and Ehrlichia spp., while one specimen was infected by C. burnetii, Rickettsia spp., and Bartonella spp. The double infection observed in Hae. erinacei was either with C. burnetii and Rickettsia spp. (12/92; 13\%) or with C. burnetii and Ehrlichia spp. (10/92; $10.8 \%)$.

A total of 10 Rh. sanguineus (66.6\%) were co-infected with C. burnetii and Rickettsia massiliae, while two Rh. sanguineus $(2 / 15,13.3 \%)$ presented a triple infection with C. burnetii, R. massiliae, and Borrelia sp. or Anaplasma sp.

Fleas also presented multiple infections, 30.8\% (28/91) of A. erinacei were co-infected with at least two pathogens. Double infections were observed in 29.6\% (27/91) of A. erinacei, including C. burnetii and R. asembonensis $(n=26)$, and Bartonella spp. and Rickettsia spp. $(n=1)$. Triple infection with C. burnetii, Bartonella spp., and Rickettsia spp. was detected in one A. erinacei. Moreover, Ctenocephalides felis $(1 / 1)$ also presented a co-infection with $C$. burnetii and Rickettsia spp.

\section{Discussion}

Wild animals such as hedgehogs can serve a reservoir role for several zoonotic pathogens and thus represent a major public health concern, affecting all continents. In our study, all captured hedgehogs in North Tunisia were identified as Atelerix algirus. This small mammal is considered the main hedgehog species in Tunisia. It is an endemic animal of the Maghreb region (Morocco, Algeria, Tunisia and Libya) where it colonizes a wide variety of biotopes. In contrast, the second most common hedgehog species encountered in Tunisia is Paraechinus aethiopicus; it is recorded in the center and the south, with a specialization in the arid and Saharan environment, and can live in sympatry with A. algirus [10,12].

The studied hedgehogs were infested by four tick taxa: Haemaphysalis erinacei, Rhipicephalus sanguineus, Ixodes spp., and Hyalomma aegyptium; and two flea species: Archaeopsylla erinacei and Ctenocephalides felis. Similar results have been reported in Algeria, where Atelerix algirus were infested by $R h$. sanguineus and Hae. erinacei ticks and Archaeopsylla erinacei fleas $[18,19,32]$. In Europe, hedgehogs have been reported to be infested by Ixodes ricinus, Ixodes hexagonus, and Archaeopsylla erinacei [15-17]. In this study, we screened hedgehogs and their infesting arthropod vectors (ticks and fleas) for VBPs. In this context, a positive tick or flea meant it contained similar DNA sequences to targeted genes of VBPs, but this did not necessarily mean that the VBP was actually present in the arthropod [36]. Identification of pathogens' DNA in these ectoparasites suggests its presence and circulation in the studied localities, but these arthropod species are not necessarily their biological vectors. However, it should be noted that in this survey, the main pathogens were most often identified in their natural vector as well as in their reservoir hosts, suggesting a stronger link between a pathogen, its natural vector, and the wild host than with other arthropod vector species. 


\subsection{Coxiella burnetii in Hedgehogs, Ticks and Fleas}

Using microfluidic real-time PCR tests, we detected Coxiella burnetii DNA, the pathogenic agent of $\mathrm{Q}$ fever, in two A. algirus from Bizerte region. This mammal was positive in more than one biopsy, suggesting possible amplification of the pathogen in hedgehog organs. Our results are consistent with those of a recent study which reported the infection of Erinaceus amurensis hedgehogs in China by C. burnetii [30]. However, hedgehogs are known to carry the etiological agent of $Q$ fever [37], since C. burnetii antibodies have been detected among 64 tested European hedgehogs in Austria [38]. Moreover, C. burnetii has also been described worldwide in domestic and wild animals, such as red foxes, rodents, and wild birds [39-41], while reservoirs are extensive but not accurately identified [42].

This study also provides the first detection of C. burnetii in hedgehog's Haemaphysalis erinacei tick and Archaeopsylla erinacei flea. To our knowledge, this bacterium has never been detected in these tick and flea species; therefore, we may defend the hypothesis that hedgehog fleas and ticks may be vectors of $C$. burnetii among wild mammals. Data about flea infection with $C$. burnetii are scarce, but this pathogen has been reported in other flea species, such as Ctenocephalides canis and C. felis, and Xenopsylla cheopis infesting foxes and rats, respectively $[43,44]$.

Likewise, in this study, we report C. burnetii DNA in Rh. sanguineus, the brown dog tick collected from hedgehogs. This tick species is known to harbor this pathogen $[45,46]$. Coxiella burnetii was also isolated from $R h$. sanguineus infesting a dog naturally affected by $Q$ fever [47]. In Algeria, a neighboring country to Tunisia, C. burnetii has recently been detected in Ixodes vespertilionis ticks infesting bats, but not in Rh. sanguineus infesting the $A$. algirus hedgehog [32]. Our data are worrisome in the context of a one health approach, as $R h$. sanguineus is widespread and may also feed on a wide range of domestic and wild animals, as well as on humans [48]. In this context, we hypothesize that $A$. algirus hedgehogs in Tunisia could be an efficient wild reservoir for C. burnetii and could participate in its enzootic cycle, which involves ticks and fleas enhancing the exposure of domestic animals and humans to this zoonotic and pathogenic agent. In addition, Coxiella burnetii infection has recently been reported in dromedary camels in Tunisia [49], and the bacterium infests Hyalomma dromedarii and Hy. impeltatum ticks [50]. In Tunisia, clinical $Q$ fever is rarely reported by physicians, yet the genome of this pathogen has been sequenced from the heart valve of a Tunisian patient with severe infective endocarditis [51]. However, given the highly conserved nature of the 16S rRNA genes among Coxiella species, these results should be further confirmed by targeting other genes, as Coxiella in ticks may be Coxiella-like organisms [52-54].

\subsection{Rickettsia spp. in Hedgehogs and Haemaphysalis erinacei Ticks}

Rickettsia DNA was detected in two A. algirus and their infesting Hae. erinacei ticks from the Bizerte and Kef regions. Thus, horizontal transmission of Rickettsia spp. between Hae. erinacei ticks and A. algirus hedgehogs may occur. Among these two positive hedgehogs, one was infected in three different organs. This means that possible amplification of the pathogen in hedgehog organs may occur. As a result, A. algirus hedgehogs may play an important role in the enzootic cycle of this bacterium and could be a reservoir. In the same context, hedgehogs in China constitute potential reservoirs of $R$. sibirica sibirica (the agent of Siberian tick typhus), and its DNA was detected in feeding ticks [55]. Our results on infection of Hae. erinacei ticks by Rickettsia spp. corroborate those reported in Algeria, where Hae. erinacei collected from A. algirus hedgehogs were shown to be infected with Rickettsia sp. and R. heilongjiangensis [19]. Moreover, other Rickettsia species, such as Rickettsia sibirica subsp. mongolitimonae and Rickettsia raoultii, were also reported in Hae. erinacei infesting hedgehogs in Turkey [56] and marbled polecats at the China-Kazakhstan border, respectively [57]. As Hae. erinacei is known to feed on humans [58,59], potential infection of people who are in close contact with hedgehogs by these infectious agents should be considered. 


\subsection{Rickettsia massiliae in Rhipicephalus sanguineus Ticks}

Our analysis revealed that 8 of 15 tested Rh. sanguineus, collected from A. algirus, were positive for R. massiliae. Accordingly, R. massiliae has previously been detected in Rh. sanguineus ticks collected from domestic animals (dogs, sheep, and goats) in Tunisia [60,61]. In accordance with our results, $R$. massiliae was also detected in Rh. sanguineus collected from A. algirus and Erinaceus europaeus in Algeria and France, respectively [19,62]. Additionally, $R$. massiliae was detected in Rh. sanguineus and Rh. turanicus collected from wild and domestic animals in France, Spain, and Greece [62-66]. Therefore, the hedgehog may play a reservoir role for this Rickettsia species that may infect humans. Although few human cases have been reported [67-69], the pathogen was isolated in one case in Italy [70].

\subsection{Rickettsia massiliae in Fleas and Rickettsia lusitaniae in Rhipicephalus sanguineus}

Interestingly, we report $R$. massiliae in one A. erinacei flea. To our knowledge, this is the first report of $R$. massiliae DNA in a flea, since it is known to be primarily transmitted by ticks. In the same context, microorganisms that are considered tick-borne pathogens have been reported in fleas, such as Babesia microti in Orchopeas leucopus fleas collected from Peromyscus leucopus [71]. Similarly, Anaplasma phagocytophilum DNA was identified in fleas collected from red foxes [72] and Borrelia burgdorferi has been identified in fleas feeding on small mammals $[73,74]$. However, our results do not imply that fleas may be vectors of $R$. massiliae, as detection of this pathogen's DNA may correspond to remains reflecting the fact that the engorged fleas co-infested with ticks on the same hedgehog.

In fact, in our investigation, the flea infected with $R$. massiliae was collected on a negative animal and thus does not relate to the hedgehog's infection. Therefore, we hypothesize that (i) this hedgehog may have an infection that was not detectable at the time of sampling; (ii) this positive flea may have infested another, infected, host before infesting the tested negative hedgehog; or (iii) this flea acquired $R$. massiliae by co-feeding with an infected tick. In our case, the latter hypothesis may be explained by the fact that Hae. erinacei and Rh. sanguineus ticks collected from the same hedgehog were found to be infected by Rickettsia spp., and we already reported in this study the infection of $R h$. sanguineus collected from other hedgehogs with $R$. massiliae. Nevertheless, to our knowledge, co-feeding between ticks and fleas has not been described before; only cofeeding between infected and naïve ticks [75-77], as well as between infected and naïve fleas [78].

Our study also revealed for the first time in Tunisia the presence of Rickettsia lusitaniae in a specimen of $R h$. sanguineus. Interestingly, the other $R h$. sanguineus ticks collected on the same hedgehog were infected with $R$. massiliae, while this animal was Rickettsia spp.-negative. Thus, the origin of $R$. lusitaniae infection remains unknown, since no data are available about its occurrence in hard ticks, while it has only been associated with Argasidae ticks, such as Ornithodoros erraticus in Portugal [79], Ornithodoros yumatensis in Mexico [80], and Argas vespertilionis in China [81,82]. Moreover, in Tunisia, O. erraticus tick species [83], a confirmed competent vector of $R$. lusitaniae, was collected in habitats of small wild mammals (rodents), which suggested this tick species may also feed on hedgehogs.

\subsection{Rickettsia asembonensis in Fleas}

The third Rickettsia species detected in 71 of 91 (78\%) tested Archaeopsylla erinacei fleas was Rickettsia asembonensis. Our results corroborated the unique reports made in Germany and Portugal, where R. asembonensis was detected in A. erinacei fleas collected from Erinaceus europaeus hedgehogs $[84,85]$. In contrast, Rickettsia felis, the agent of flea-borne spotted fever, was the common pathogen in A. erinacei sampled from European and North African hedgehogs [19,32,62,86], as well as from cats, dogs [87], and foxes [63]. To our knowledge, this is the first report of the occurrence of $R$. asembonensis in the Maghreb region; however, in Egypt, this Rickettsia was described in Echidnophaga gallinacea fleas [43]. Moreover, $R$. asembonensis DNA has been detected in other flea species within the cosmopolitan Pulicidae family [88], such as Ctenocephalides felis, where it was isolated [89]. This pathogen has mostly 
been detected in C. felis fleas collected from dogs, cats, and humans in Mexico, Brazil, USA, India, Malaysia, Rwanda, and Kenya [90-98]. Furthermore, R. asembonensis DNA has been detected in Rhipicephalus sanguineus ticks in Brazil [99] and Malaysia [100]. In addition, $R$. asembonensis was detected in cynomolgus monkeys (Macaca fascicularis) in Malaysia [101] and in cats in Thailand [102]. Given the expansion of the host range of the hedgehog flea $A$. erinacei, it may contribute to the dissemination of $R$. asembonensis in different domestic and wild animal hosts and humans. Importantly, A. erinacei fleas have been reported feeding on humans causing purpura pulicosa $[103,104]$. Moreover, recent studies reported the association of R. asembonensis with human pathogenicity in Peru [105] and Malaysia [106].

\subsection{Ehrlichia ewingii and Candidatus Ehrlichia shimanensis in Hedgehogs and Haemaphysalis erinacei Ticks}

Interestingly, Ehrlichia ewingii, the etiologic agent of human granulocytic ehrlichiosis (HGE), was detected in Hae. erinacei ticks and in the blood of one A. algirus. This suggests that $A$. algirus may be a reservoir for this zoonotic microorganism, and horizontal transmission between this hedgehog and its infesting ticks may occur. Ehrlichia ewingii DNA has been reported in Haemaphysalis flava collected from hedgehogs in China [107]. In Tunisia, an Ehrlichia species closely related to E. ewingii were detected in Ixodes ricinus and Hyalomma scupense [108]. This may suggest active circulation of this pathogen in Tunisia.

However, another genotype of Ehrlichia spp., closely related to Candidatus Ehrlichia shimanensis, was only detected in hedgehog tissue samples. This emergent Ehrlichia pathogen was first described in Haemaphysalis longicornis by Kawahara et al., in 2006 [109] as a novel Ehrlichia species phylogenetically close to three zoonotic Ehrlichia species: E. muris, E. ewingii, and E. chaffeensis. Recently, Ca. E. shimanensis was detected in ticks collected from cattle in Malaysia [110]. Genetic variants closely related to the Ca. E. shimanensis group were reported in Haemaphysalis ticks in Japan [111]. We suggest that $A$. algirus hedgehogs in Tunisia may be reservoir hosts for these emerging Ehrlichia species. However, given the highly conserved nature of the 16S rRNA genes, further investigations are required to attempt to genotype these genetic variants.

\subsection{Theileria youngi and Hepatozoon sp. in Hedgehogs}

In this study, we reported for the first time Theileria youngi in hedgehogs in Northern Tunisia. Consistent with our results, in Saudi Arabia, four T. youngi haplotypes were detected in Paraechinus aethiopicus hedgehogs [112]. In addition, other Theileria species were reported in hedgehogs in China, such as T. lunwenshuni and Theileria sp. [113]. Theileria spp. have been reported to infect several wild and domestic animals as well as their infesting ticks [114-118]. Furthermore, several Theileria species, such as T. annulata and T. lestoquardi, were reported in Tunisia in small ruminants, cattle, horses, and ticks [119-121].

Additionally, Hepatozoon sp. DNA was detected in the liver of one hedgehog. To our knowledge, this is the first report of Hepatozoon spp. in hedgehogs. These pathogens have been detected in several wild and domestic animals [122-125]. In Tunisia, zoonotic Hepatozoon canis has been described in dogs [126].

\subsection{Anaplasma sp. and Borrelia sp.}

Anaplasma sp. DNA was detected in one $R h$. sanguineus tick. It clustered with $A$. phagocytophilum detected in ticks and ruminants in China and Portugal [127,128], Candidatus Anaplasma boleense detected in ticks and mosquitoes in China [129,130], and uncharacterized Anaplasma species in ticks from China [129]. Given the highly conserved nature of the $16 \mathrm{~S}$ rRNA genes, our results need further investigation, since in Tunisia, Anaplasma spp. have been detected in various domestic animals and ticks [131]. Moreover, Erinaceus europaeus hedgehogs have been reported to be a reservoir for Anaplasma spp. and A. phagocytophilum [25,26,132]. Recently, Anaplasma marginale was reported in long-eared hedgehogs, Hemiechinus auritus, and their Rhipicephalus turanicus ticks in Iran [133].

Here, we also report the presence of Borrelia DNA in one Rh. sanguineus collected from a non-Borrelia infected $A$. algirus hedgehog. The related sequence clustered with 
uncharacterized Borrelia species from Iran and Portugal [134], and with relapsing fever Borrelia species, such as B. theileri detected in Rhipicephalus geigyi from Mali [135] and B. lonestari detected in ticks collected from humans in the USA [136]. Borrelia burgdorferi s. 1. genospecies have also been reported in Erinaceus europaeus and E. roumanicus hedgehogs and their infesting ticks $[137,138]$. In Tunisia, Borrelia species were also reported in ticks, cattle, ruminants, and camels $[139,140]$.

\subsection{Bartonella spp. in Ticks and Fleas}

Finally, we reported Bartonella spp. DNA in Hae. erinacei, Rh. sanguineus ticks, and $A$. erinacei fleas. Zoonotic Bartonella species have been reported in Tunisia in fleas infesting domestic animals, stray dogs, camels, and patients [141-144]. In Algeria, Bartonella spp. were reported to infect Atelerix algirus and fleas infesting hedgehogs [31,145]. Consistent with our results, Bartonella species were detected in A. erinacei collected from the northern white-breasted hedgehog [146]. In addition, Bartonella spp. were reported to occur in wildlife and their infesting arthropods in Madagascar, China, Mexico, Brazil, Norway, and Thailand [147-152].

\subsection{Co-Infections in Hedgehogs, Ticks, and Fleas}

In this study, we reported co-infections in Atelerix algirus hedgehogs, ticks, and fleas with at least two VBPs. These results shed light on the potential role of Atelerix algirus hedgehogs as simultaneous wild reservoir of zoonotic pathogens of medical and veterinarian interest. Similar observations on double (Borrelia burgdorferi and Anaplasma phagocytophilum) infections in ticks infesting hedgehogs were reported in Ixodes ricinus collected from E. europaeus hedgehogs in Germany [132]. In addition, E. europaeus hedgehogs were reported to be co-infected by several Borrelia species, such as B. afzelii, B. bavariensis, and B. spielmani [138].

\section{Materials and Methods}

\subsection{Experimental Design}

In this study, we screened hedgehogs, and their infesting ticks and fleas for VBP infection using a high-throughput microfluidic real-time PCR system. The experimental design is shown in Figure 8.

\subsection{Study Location and Sample Collection}

A total of 20 hedgehogs were captured alive at night, in rural and suburban areas close to inhabited houses (Table 1). A total of 10 hedgehogs were captured during a monitoring study of sporadic cutaneous leishmaniasis in an endemic area in Northern Tunisia, in two localities (Zaafrane and, Abida) in the El Kef governorate. In addition, 10 hedgehogs were captured in three localities (Dahmani, Oued Souani, and Kalaat Senan) in the El Kef governorate $(n=3)$, five localities (Metline, El Garia, Bazina, Bni Atta, and Joumine,) in the Bizerte governorate $(n=6)$, and one locality in the Kasserine governorate $(n=1)$.

\subsection{Sample Processing and DNA Extraction}

Captured animals were transferred to Institut Pasteur de Tunis. The corresponding genus and species of each captured specimen were determined based on external morphological criteria [10].

The animals were carefully examined for the presence of ticks and fleas. The ectoparasites vectors were collected from hedgehogs using fine forceps, and were identified to the species level using corresponding identification keys $[58,153,154]$. Specimens were then stored at $-80^{\circ} \mathrm{C}$ until DNA extraction. Hedgehogs were then euthanized and biopsies from the organs were taken, labeled and stored at $-80^{\circ} \mathrm{C}$ for further analyses.

For DNA extraction, ticks and fleas were processed individually; each specimen was first washed in 70\% ethanol, then rinsed twice in sterile distilled water, and well dried on sterile filter paper. Biopsies and arthropod samples were mechanically homogenized in 
$80 \mu \mathrm{L}$ PBS using an Omni Bead Ruptor 24 (Omni International Inc., Kennesaw, GA, USA) and $2.8 \mathrm{~mm}$ ceramic beads for 3 cycles at $6 \mathrm{~m} / \mathrm{s}$ for $1 \mathrm{~min}$. Homogenized samples were immediately used for genomic DNA extraction using a DNeasy Blood \& Tissue Kit (Qiagen, Hilden, Germany), following the manufacturer's instructions. Quality and quantity of the extracted DNA were evaluated using a spectrophotometer (NanoDrop ${ }^{\circledR}$, Germany).

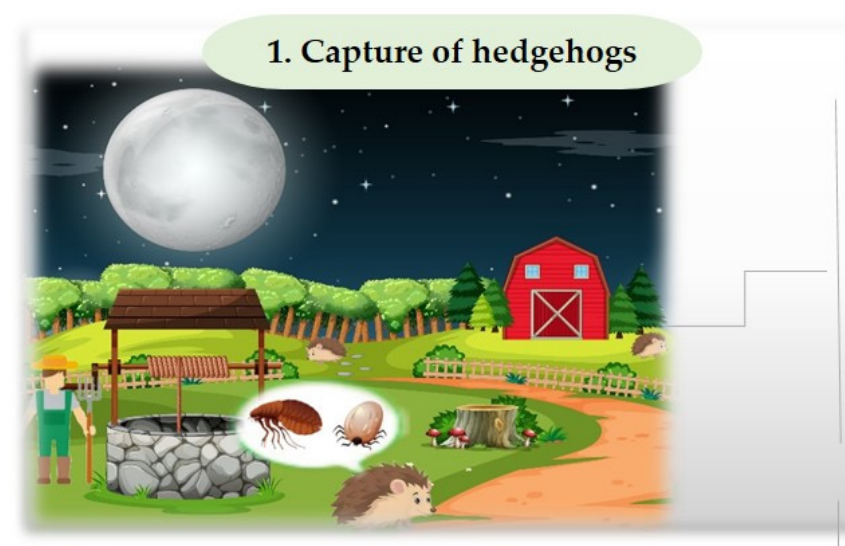

3. DNA Preamplification
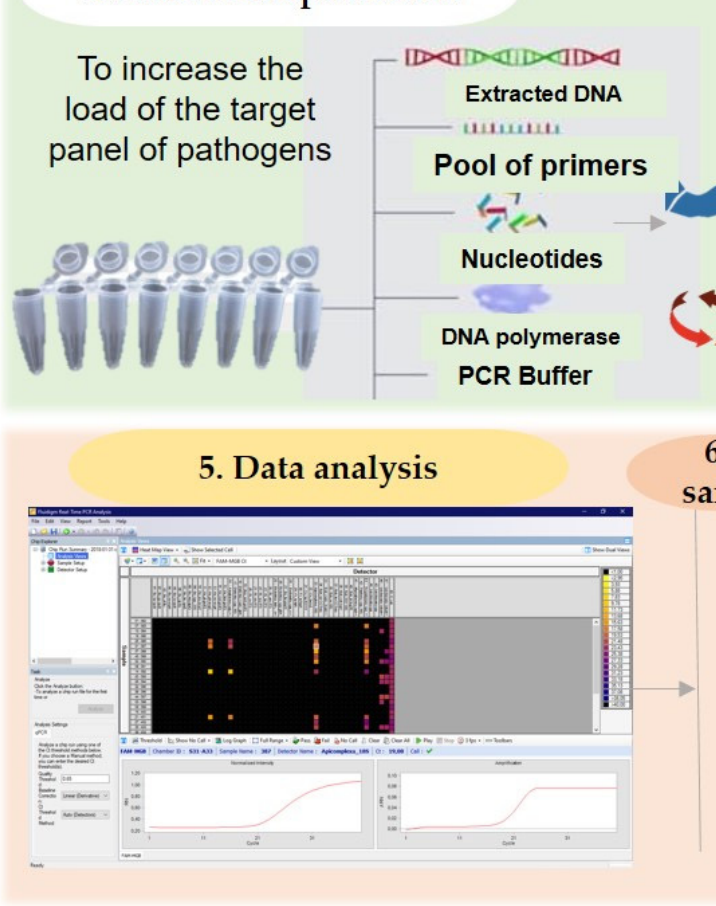

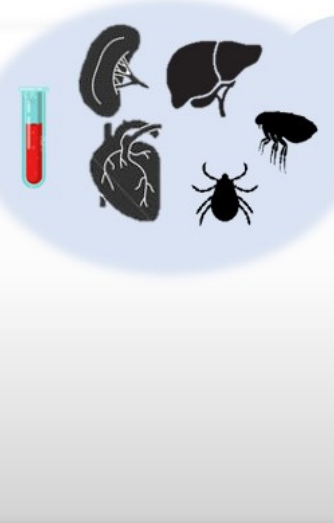

\section{Sample processing and DNA extraction}

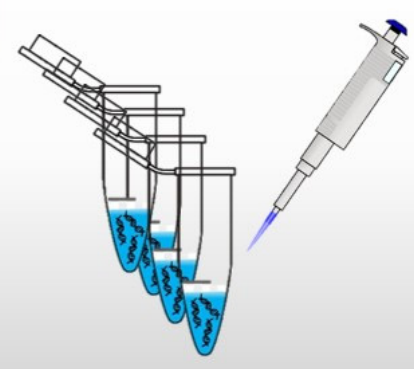

4. Microfluidic real-time

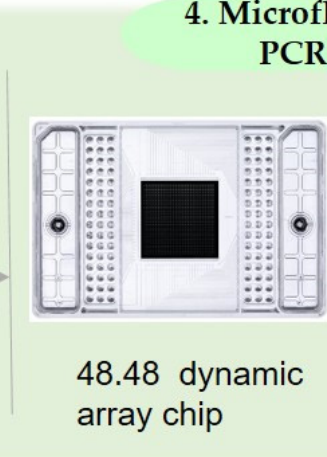

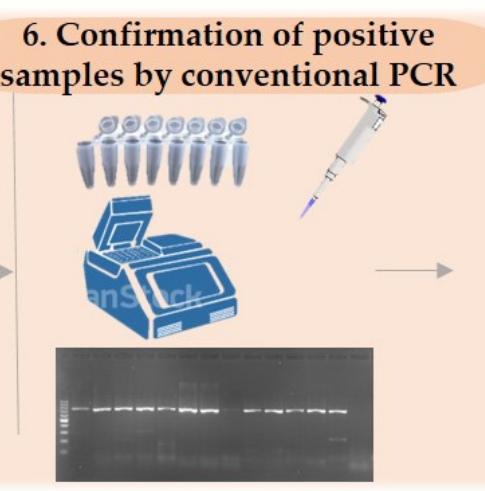

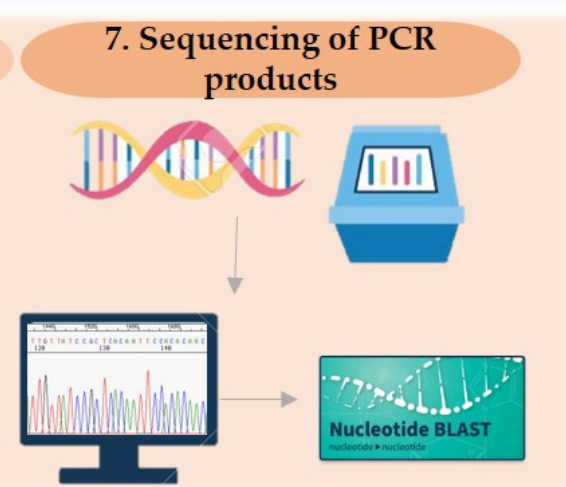

Figure 8. Schematic representation of the workflow used in this study.

\subsection{DNA Pre-Amplification}

DNA was pre-amplified in order to increase the pathogenic load in the sample prior to microfluidic real-time PCR screening using the Fluidigm PreAmp Master Mix (Fluidigm, San Francisco, CA, USA), according to the manufacturer's instructions. A mixture of pathogen-specific primers was prepared by pooling equal volumes of forward and reverse primers of each targeted pathogen at a final concentration of $200 \mathrm{nM}$ each. The reactions were performed in $5 \mu \mathrm{L}$ as a final volume, containing $1 \mu \mathrm{L}$ Fluidigm PreAmp Master Mix, $1.25 \mu \mathrm{L}$ pooled primers mix, $1.5 \mu \mathrm{L}$ Milli-Q water, and 1.25 $\mu \mathrm{L}$ DNA. A negative control, containing water instead of DNA, was added to each reaction. Pre-amplification reactions were performed using the following cycling program; one step at $95{ }^{\circ} \mathrm{C}$ for $2 \mathrm{~min}, 14$ cycles 
at $95^{\circ} \mathrm{C}$ for $15 \mathrm{~s}$, and $4 \mathrm{~min}$ at $60^{\circ} \mathrm{C}$. The obtained pre-amplifcation products were diluted 1:10 and stored at $-20^{\circ} \mathrm{C}$ until microfluidic real-time PCR testing.

\subsection{High-Throughput Real-Time PCR Screening}

High-throughput microfluidic real-time PCR amplifications were performed using the BioMark $^{\mathrm{TM}}$ real-time PCR system (Fluidigm, San Francisco, CA, USA) and 48.48 dynamic arrays enabling up to 2304 individual reactions to be performed in one run. Primers and probes used in this study are summarized in supplementary Table S1. Real-time PCRs were performed using 6-carboxyfluorescein (6-FAM) and black hole quencher (BHQ1)-labeled TaqMan probes with PerfeCTa ${ }^{\circledR}$ qPCR ToughMix ${ }^{\circledR}$, Low ROX ${ }^{\mathrm{TM}}$ (Quanta Biosciences, Gaithersburg, MD, USA) following Michelet et al., 2014 [155]. The cycling conditions were as follows: $2 \mathrm{~min}$ at $50{ }^{\circ} \mathrm{C}$ and $10 \mathrm{~min}$ at $95^{\circ} \mathrm{C}$, followed by 40 cycles of two-step amplification for $15 \mathrm{~s}$ at $95^{\circ} \mathrm{C}$ and $1 \mathrm{~min}$ at $60^{\circ} \mathrm{C}$.

Three controls were included in each dynamic array chip: a negative water control to exclude contamination, a DNA extraction control (primers and probes targeting the $16 \mathrm{~S}$ rRNA gene of ticks), and an internal control to exclude PCR inhibitors (Escherichia coli DNA strain EDL933 with specific primers and probes targeting the eae gene) [156]. Acquired data were analyzed using the Fluidigm real-time PCR Analysis Software (Fluidigm, USA).

\subsection{Validation of Results by Conventional PCR, Nested PCR, and Sequencing}

Conventional PCR/nested PCR using primers (Table 4) targeting genes or regions different from those targeted by microfluidic real-time PCR was carried out to confirm the infection by a specific pathogen (Table 4). PCR products were then sequenced by Sanger sequencing (Biomnis-Eurofins Genomics, Lyon, France). Sequences were analyzed using BioEdit Software (Ibis Biosciences, Carlsbad, CA, USA). The BLAST program (http: / / www.ncbi.nlm.nih.gov / BLAST (accessed on 12 January 2021)) was used to compare and analyze the sequence data.

Table 4. Primers used in conventional PCR/nested PCR to confirm microfluidic real-time PCR results.

\begin{tabular}{|c|c|c|c|c|c|}
\hline Pathogen & Targeted Gene & Primers & Sequence $\left(5^{\prime}-3^{\prime}\right)$ & Amplicon Size (bp) & Reference \\
\hline \multirow{3}{*}{ Rickettsia spp. } & gltA & $\begin{array}{l}\text { Rsfg877 } \\
\text { Rsfg1258 }\end{array}$ & $\begin{array}{l}\text { GGGGGCCTGCTCACGGCGG } \\
\text { ATTGCAAAAAGTACAGTGAACA }\end{array}$ & 381 & [157] \\
\hline & \multirow{2}{*}{ ompB } & $\begin{array}{l}\text { Rc.rglt. } 4362 \mathrm{p} \\
\text { Rc.rompB.4836n }\end{array}$ & $\begin{array}{l}\text { GTCAGCGTTACTTCTTCGATGC } \\
\text { CCGTACTCCATCTTAGCATCAG }\end{array}$ & 475 & \multirow{2}{*}{ [158] } \\
\hline & & $\begin{array}{l}\text { Rc.rompB.4496p } \\
\text { Rc.rompB.4762n }\end{array}$ & $\begin{array}{l}\text { CCAATGGCAGGACTTAGCTACT } \\
\text { AGGCTGGCTGATACACGGAGTAA }\end{array}$ & 267 & \\
\hline Anaplasma/Ehrlichia spp. & 16S rRNA & $\begin{array}{l}\text { EHR1 } \\
\text { EHR2 } \\
\text { EHR3 }\end{array}$ & $\begin{array}{c}\text { GAACGAACGCTGGCGGCAAGC } \\
\text { AGTA(T/C)CG(A/G)ACCAGATAGCCGC } \\
\text { TGCATAGGAATCTACCTAGTAG }\end{array}$ & 629 & [159] \\
\hline Hepatozoon spp. & $18 \mathrm{~S}$ rRNA & $\begin{array}{l}\text { HepF } \\
\text { HepR }\end{array}$ & $\begin{array}{l}\text { ATACATGAGCAAAATCTCAAC } \\
\text { CTTATTATTCCATGCTGCAG }\end{array}$ & 660 & [160] \\
\hline \multirow{3}{*}{ Theileria spp. } & \multirow{3}{*}{ 18S rRNA } & $\begin{array}{l}\text { BABGF2 } \\
\text { BABGR2 }\end{array}$ & $\begin{array}{l}\text { GYYTTGTAATTGGAATGATGG } \\
\text { CCAAAGACTTTGATTTCTCTC }\end{array}$ & 559 & [161] \\
\hline & & $\begin{array}{l}\text { BTH 18S 1st F } \\
\text { BTH 18S 1st }\end{array}$ & $\begin{array}{l}\text { GTGAAACTGCGAATGGCTCATTACR } \\
\text { AAGTGATAAGGTTCACAAAACTTCCC }\end{array}$ & $1500 \mathrm{bp}$ & \multirow{2}{*}{ [162] } \\
\hline & & $\begin{array}{l}\text { BTH 18S 2nd F } \\
\text { BTH 18S 2nd R }\end{array}$ & $\begin{array}{l}\text { GGCTCATTACAACAGTTATAGTTTATTTG } \\
\text { CGGTCCGAATAATTCACCGGAT }\end{array}$ & 1500 & \\
\hline \multirow{2}{*}{$\begin{array}{l}\text { Coxiella burnetii and } \\
\text { Coxiella-like } \\
\text { endosymbionts }\end{array}$} & \multirow{2}{*}{ 16S rRNA } & $\begin{array}{l}\text { Cox 16SF1 } \\
\text { Cox 16SR1 }\end{array}$ & $\begin{array}{l}\text { CGTAGGAATCTACCTTRTAGWGG } \\
\text { ACTYYCCAACAGCTAGTTCTCA }\end{array}$ & $719-813$ & \multirow{2}{*}{ [52] } \\
\hline & & $\begin{array}{l}\text { Cox 16SF2 } \\
\text { Cox 16SR2 }\end{array}$ & $\begin{array}{l}\text { TGAGAACTAGCTGTTGGRRAGT } \\
\text { GCCTACCCGCTTCTGGTACAATT }\end{array}$ & 625 & \\
\hline \multirow{2}{*}{ Borrelia spp. } & \multirow{2}{*}{ flaB } & $\begin{array}{l}\text { FlaB280F } \\
\text { FlaRL }\end{array}$ & $\begin{array}{l}\text { GCAGTTCARTCAGGTAACGG } \\
\text { GCAATCATAGCCATTGCAGATTGT }\end{array}$ & 645 & \multirow{2}{*}[163]{} \\
\hline & & $\begin{array}{l}\text { FlaB737F } \\
\text { FlaLL }\end{array}$ & $\begin{array}{l}\text { GCATCAACTGTRGTTGTAACATTAACAGG } \\
\text { ACATATTCAGATGCAGACAGAGGT }\end{array}$ & 407 & \\
\hline Bartonella spp. & gltA & $\begin{array}{c}\text { bart781 } \\
\text { bart1137 }\end{array}$ & $\begin{array}{c}\text { GGG GAC CAG CTC ATG GTG G } \\
\text { AAT GCA AAA AGA ACA GTA AAC A }\end{array}$ & $380-400$ & [164] \\
\hline
\end{tabular}




\subsection{Phylogenetic Tree Construction}

Sequence alignments were performed using Muscle Software [165]. Maximum likelihood trees were generated by 1000 bootstrap repetitions based on the General Time Reversible model for Anaplasma spp., Ehrlichia spp., Borrelia spp., and Theileria/Hepatozoon spp. trees and the Kimura 2 parameter model and Tamura-Nei model for Rickettsia spp. and Rickettsia massiliae trees respectively, with MEGAX software [166]. The initial trees for the heuristic search were obtained automatically by applying neighbor-joining and BioNJ algorithms to a matrix of pairwise distances estimated using the maximum composite likelihood (MCL) approach, and then selecting the topology with a superior log likelihood value. The trees were drawn to scale, with branch lengths measured in the number of substitutions per site [167]. The codon positions included were 1st + 2nd + 3rd + Noncoding. All positions containing gaps and missing data were eliminated.

\section{Conclusions}

Hedgehogs are hosts of hematophagous arthropods and may be considered competent reservoirs for several arthropod-borne zoonotic pathogens in Tunisia. However, it will be necessary to confirm the circulation of the identified pathogens, as the Atelerix algirus hedgehog is a peri-urban dweller, and to determine their possible dissemination to other wildlife and their infesting arthropod vectors. Our results are of concern from a medical standpoint as several zoonotic pathogens were detected in hedgehogs and their infesting arthropod vectors in different localities. These results emphasize the need for accurate surveillance of hedgehogs and their ticks and fleas. This may help prevent possible exposure risks in humans.

Supplementary Materials: The following are available online at https:/ /www.mdpi.com/article/10 .3390 / pathogens10080953/s1, Table S1: List of primers and probes used on the BioMark ${ }^{\mathrm{TM}}$ system for this study.

Author Contributions: Conceptualization, Y.M.; methodology, G.B., M.D., H.S., A.B., S.G., S.M. and C.G.; formal analysis, G.B., C.G. and S.M.; investigation, G.B., J.C., A.R. and Y.M.; writing-original draft preparation, G.B.; writing — review and editing G.B., Y.M., A.B., I.G., S.G. and S.M.; funding acquisition, Y.M., S.G., I.G., A.B. and S.M. All authors have read and agreed to the published version of the manuscript.

Funding: This research was funded by Institut Pasteur de Tunis- Projet collaboratif interne PCI20and the Ministry of Higher Education and Scientific Research- Laboratory Viruses, Vectors and Hosts (LR20IPT02), Ecole doctorale Sciences et technologie du vivant et sciences de la terre de la faculté des sciences de Tunisand S.M.'s research was supported by the French Agency for Food, Environmental and Occupational Health and Safety (ANSES). UMR BIPAR is supported by the French Government's Investissement d'Avenir program, Laboratoire d'Excellence "Integrative Biology of Emerging Infectious Diseases" (grant No. ANR-10-LABEX-62-IBEID).

Institutional Review Board Statement: The study was conducted according to the guidelines of the Declaration of Helsinki, and approved by the Institutional Ethics Committee of Institut Pasteur de Tunis-Université Tunis El Manar-TUNISIA (2017/11/I/LR11IPT03).

Informed Consent Statement: Not applicable.

Data Availability Statement: Not applicable.

Conflicts of Interest: The authors declare that they have no conflict of interest. The funders had no role in the design of the study, in the collection, analysis, or interpretation of data, in the writing of the manuscript, or in the decision to publish the results. 


\section{References}

1. Jones, K.E.; Patel, N.G.; Levy, M.A.; Storeygard, A.; Balk, D.; Gittleman, J.L.; Daszak, P. Global Trends in emerging infectious diseases. Nature 2008, 451, 990-993. [CrossRef]

2. Dantas-Torres, F. Climate change, biodiversity, ticks and tick-borne diseases: The butterfly effect. Int. J. Parasitol. Parasites Wildl. 2015, 4, 452-461. [CrossRef]

3. Keesing, F.; Ostfeld, R.S. Is biodiversity good for your health? Science 2015, 349, 235-236. [CrossRef]

4. Levi, T.; Massey, A.L.; Holt, R.D.; Keesing, F.; Ostfeld, R.S.; Peres, C.A. Does biodiversity protect humans against infectious disease? Ecology 2016, 97, 536-542. [CrossRef]

5. Hollingsworth, T.D.; Pulliam, J.R.C.; Funk, S.; Truscott, J.E.; Isham, V.; Lloyd, A.L. Seven challenges for modelling indirect transmission: Vector-borne diseases, macroparasites and neglected tropical diseases. Epidemics 2015, 10, 16-20. [CrossRef]

6. Tomassone, L.; Berriatua, E.; De Sousa, R.; Duscher, G.G.; Mihalca, A.D.; Silaghi, C.; Sprong, H.; Zintl, A. Neglected vector-borne zoonoses in Europe: Into the wild. Vet. Parasitol. 2018, 251, 17-26. [CrossRef]

7. Evensen, D.T. Wildlife disease can put conservation at risk. Nature 2008, 452, 282. [CrossRef] [PubMed]

8. Braks, M.; Medlock, J.M.; Hubalek, Z.; Hjertqvist, M.; Perrin, Y.; Lancelot, R.; Duchyene, E.; Hendrickx, G.; Stroo, A.; Heyman, P.; et al. Vector-borne disease intelligence: Strategies to deal with disease burden and threats. Front. Public Health 2014, 2, 280. [CrossRef] [PubMed]

9. Rizzoli, A.; Tagliapietra, V.; Cagnacci, F.; Marini, G.; Arnoldi, D.; Rosso, F.; Rosà, R. Parasites and wildlife in a changing world: The vector-host-pathogen interaction as a learning case. Int. J. Parasitol. Parasites Wildl. 2019, 9, 394-401. [CrossRef]

10. Corbet, G.B. The family erinaceidae: A synthesis of its taxonomy, phylogeny, ecology and zoogeography. Mamm. Rev. 1988, 18, 117-172. [CrossRef]

11. He, K.; Chen, J.-H.; Gould, G.C.; Yamaguchi, N.; Ai, H.-S.; Wang, Y.-X.; Zhang, Y.-P.; Jiang, X.-L. An estimation of erinaceidae phylogeny: A combined analysis approach. PloS ONE 2012, 7, e39304. [CrossRef]

12. Reeve, N. Hedgehogs; T. \& AD Poyser: London, UK, 1994; ISBN 978-0-85661-081-3.

13. El-Farhati, H.; Jaziri, B.; Hizem, M.W.; Nouira, S. Distribution, bioclimatic niche and sympatry of two erinaceidae in Tunisia. Afr. J. Ecol. 2020, 58, 193-210. [CrossRef]

14. Egli, R. Comparison of Physical Condition and Parasite Burdens in Rural, Suburban and Urban Hedgehogs Erinaceus europaeus: Implications for Conservation. Ph.D. Thesis, Universität Bern, Bern, Germany, 2004.

15. Dziemian, S.; Sikora, B.; Piłacińska, B.; Michalik, J.; Zwolak, R. Ectoparasite loads in sympatric urban populations of the northern white-breasted and the European hedgehog. Parasitol. Res. 2015, 114, 2317-2323. [CrossRef]

16. Földvári, G.; Rigó, K.; Jablonszky, M.; Biró, N.; Majoros, G.; Molnár, V.; Tóth, M. Ticks and the City: Ectoparasites of the northern white-breasted hedgehog (Erinaceus roumanicus) in an urban park. Ticks Tick Borne Dis. 2011, 2, 231-234. [CrossRef] [PubMed]

17. Gorgani-Firouzjaee, T.; Pour-Reza, B.; Naem, S.; Tavassoli, M. Ectoparasitic infestations of the European hedgehog (Erinaceus europaeus) in Urmia City, Iran: First report. Vet. Res. Forum 2013, 4, 191-194. [PubMed]

18. Sakraoui, F.; Boukheroufa, M.; Sakraoui, W.; Madoui, M.B.E. Ectoparasitic ecology of Algerian hedgehog Ateleris algirus (Lereboullet, 1842) (Erinaceidae, Mammalia) in some localities of Edough Montain (W. Annaba, Northest Algeria). Adv. Environ. Biol. 2014, 217-222. Available online: https:/ /link.gale.com/apps/doc/A417895203/AONE?u=anon \{\}947afc63\&sid=googleScholar\& xid=e66711f2 (accessed on 12 January 2021).

19. Khaldi, M.; Socolovschi, C.; Benyettou, M.; Barech, G.; Biche, M.; Kernif, T.; Raoult, D.; Parola, P. Rickettsiae in arthropods collected from the North African hedgehog (Atelerix algirus) and the desert hedgehog (Paraechinus aethiopicus) in Algeria. Comp. Immunol. Microbiol. Infect. Dis. 2012, 35, 117-122. [CrossRef]

20. Pfäffle, M.; Petney, T.; Elgas, M.; Skuballa, J.; Taraschewski, H. Tick-Induced blood loss leads to regenerative anaemia in the European hedgehog (Erinaceus europaeus). Parasitology 2009, 136, 443-452. [CrossRef] [PubMed]

21. Uspensky, I. Tick pests and vectors (Acari: Ixodoidea) in European towns: Introduction, persistence and management. Ticks Tick Borne Dis. 2014, 5, 41-47. [CrossRef] [PubMed]

22. Krawczyk, A.I.; van Leeuwen, A.D.; Jacobs-Reitsma, W.; Wijnands, L.M.; Bouw, E.; Jahfari, S.; van Hoek, A.H.A.M.; van der Giessen, J.W.B.; Roelfsema, J.H.; Kroes, M.; et al. Presence of zoonotic agents in engorged ticks and hedgehog faeces from Erinaceus europaeus in (Sub) urban areas. Parasit. Vectors 2015, 8, 210. [CrossRef]

23. Gern, L.; Rouvinez, E.; Toutoungi, L.N.; Godfroid, E. Transmission cycles of Borrelia Burgdorferi Sensu Lato involving Ixodes ricinus and/or I. hexagonus ticks and the European hedgehog, Erinaceus europaeus, in suburban and urban areas in Switzerland. Folia Parasitol. 1997, 44, 309-314.

24. Skuballa, J.; Oehme, R.; Hartelt, K.; Petney, T.; Bücher, T.; Kimmig, P.; Taraschewski, H. European hedgehogs as hosts for Borrelia Spp., Germany. Emerg. Infect. Dis. 2007, 13, 952-953. [CrossRef] [PubMed]

25. Skuballa, J.; Petney, T.; Pfäffle, M.; Taraschewski, H. Molecular detection of Anaplasma phagocytophilum in the European hedgehog (Erinaceus europaeus) and its ticks. Vector Borne Zoonotic Dis. 2010, 10, 1055-1057. [CrossRef] [PubMed]

26. Silaghi, C.; Skuballa, J.; Thiel, C.; Pfister, K.; Petney, T.; Pfäffle, M.; Taraschewski, H.; Passos, L.M.F. The European hedgehog (Erinaceus europaeus)—A suitable reservoir for variants of Anaplasma phagocytophilum? Ticks Tick Borne Dis. 2012, 3, 49-54. [CrossRef] [PubMed]

27. Szekeres, S.; Docters van Leeuwen, A.; Tóth, E.; Majoros, G.; Sprong, H.; Földvári, G. Road-killed mammals provide insight into tick-borne bacterial pathogen communities within urban habitats. Transbound Emerg. Dis. 2019, 66, 277-286. [CrossRef] [PubMed] 
28. Schönbächler, K.; Hatt, J.; Silaghi, C.; Merz, N.; Fraefel, C.; Bachofen, C. Confirmation of tick-borne encephalitis virus in an European hedgehog (Erinaceus europaeus). Schweiz Arch. Tierheilkd 2019, 161, 23-31. [CrossRef] [PubMed]

29. Földvári, G.; Jahfari, S.; Rigó, K.; Jablonszky, M.; Szekeres, S.; Majoros, G.; Tóth, M.; Molnár, V.; Coipan, E.C.; Sprong, H. Candidatus neoehrlichia mikurensis and Anaplasma Phagocytophilum in urban hedgehogs. Emerg. Infect. Dis. 2014, $20,496-498$. [CrossRef] [PubMed]

30. Gong, X.Q.; Xiao, X.; Liu, J.W.; Han, H.J.; Qin, X.R.; Lei, S.C.; Yu, X.J. Occurrence and genotyping of Coxiella burnetii in hedgehogs in China. Vector Borne Zoonotic Dis. 2020, 20, 580-585. [CrossRef] [PubMed]

31. Bitam, I.; Rolain, J.-M.; Kernif, T.; Baziz, B.; Parola, P.; Raoult, D. Bartonella species detected in rodents and hedgehogs from Algeria. Clin. Microbiol. Infect. 2009, 15, 102-103. [CrossRef]

32. Leulmi, H.; Aouadi, A.; Bitam, I.; Bessas, A.; Benakhla, A.; Raoult, D.; Parola, P. Detection of Bartonella tamiae, Coxiella burnetii and rickettsiae in arthropods and tissues from wild and domestic animals in northeastern Algeria. Parasit. Vectors 2016, 9, 27. [CrossRef]

33. Tomás-Pérez, M.; Khaldi, M.; Riera, C.; Mozo-León, D.; Ribas, A.; Hide, M.; Barech, G.; Benyettou, M.; Seghiri, K.; Doudou, S.; et al. First report of natural infection in hedgehogs with Leishmania major, a possible reservoir of zoonotic cutaneous leishmaniasis in Algeria. Acta Trop. 2014, 135, 44-49. [CrossRef]

34. Chemkhi, J.; Souguir, H.; Ali, I.B.H.; Driss, M.; Guizani, I.; Guerbouj, S. Natural infection of Algerian hedgehog, Atelerix algirus (Lereboullet 1842) with Leishmania parasites in Tunisia. Acta Trop. 2015, 150, 42-51. [CrossRef] [PubMed]

35. Souguir-Omrani, H.; Chemkhi, J.; Fathallah-Mili, A.; Saadi-BenAoun, Y.; BelHadjAli, I.; Guizani, I.; Guerbouj, S. Paraechinus aethiopicus (Ehrenberg 1832) and Atelerix algirus (Lereboullet 1842) hedgehogs: Possible reservoirs of endemic leishmaniases in Tunisia. Infect. Genet. Evol. 2018, 63, 219-230. [CrossRef] [PubMed]

36. Estrada-Peña, A.; Gray, J.S.; Kahl, O.; Lane, R.S.; Nijhof, A.M. Research on the ecology of ticks and tick-borne pathogensMethodological principles and caveats. Front. Cell. Infect. Microbiol. 2013, 3, 29. [CrossRef] [PubMed]

37. Riley, P.Y.; Chomel, B.B. Hedgehog zoonoses. Emerg. Infect. Dis. 2005, 11, 1-5. [CrossRef] [PubMed]

38. Sixl, W.; Köck, M.; Withalm, H.; Stünzner, D. Serological investigations of the hedgehog (Erinaceus europaeus) in Styria. Geogr. Med. Suppl. 1989, 2, 105-108.

39. Medkour, H.; Laidoudi, Y.; Marié, J.-L.; Fenollar, F.; Davoust, B.; Mediannikov, O. Molecular investigation of vector-borne pathogens in red foxes (Vulpes vulpes) from southern france. J. Wildl. Dis. 2020, 56, 837-850. [CrossRef]

40. Bártová, E.; Kučerová, H.L.; Žákovská, A.; Budíková, M.; Nejezchlebová, H. Coxiella burnetii and Francisella tularensis in wild small mammals from the Czech Republic. Ticks Tick Borne Dis. 2020, 11, 101350. [CrossRef]

41. Tokarevich, N.K.; Panferova, Y.A.; Freylikhman, O.A.; Blinova, O.V.; Medvedev, S.G.; Mironov, S.V.; Grigoryeva, L.A.; Tretyakov, K.A.; Dimova, T.; Zaharieva, M.M.; et al. Coxiella burnetii in ticks and wild birds. Ticks Tick Borne Dis. 2019, 10, 377-385. [CrossRef]

42. Angelakis, E.; Raoult, D. Q Fever. Vet. Microbiol. 2010, 140, 297-309. [CrossRef]

43. Loftis, A.D.; Reeves, W.K.; Szumlas, D.E.; Abbassy, M.M.; Helmy, I.M.; Moriarity, J.R.; Dasch, G.A. Surveillance of Egyptian fleas for agents of public health significance: Anaplasma, Bartonella, Coxiella, Ehrlichia, Rickettsia, and Yersinia pestis. Am. J. Trop. Med. Hyg. 2006, 75, 41-48. [CrossRef] [PubMed]

44. Psaroulaki, A.; Chochlakis, D.; Ioannou, I.; Angelakis, E.; Tselentis, Y. Presence of Coxiella burnetii in fleas in Cyprus. Vector Borne Zoonotic Dis. 2014, 14, 685-687. [CrossRef]

45. Watanabe, M.; Nakao, R.; Amin-Babjee, S.M.; Maizatul, A.M.; Youn, J.H.; Qiu, Y.; Sugimoto, C.; Watanabe, M. Molecular screening for Rickettsia, anaplasmataceae and Coxiella burnetii in Rhipicephalus sanguineus ticks from Malaysia. Trop. Biomed. 2015, 32, 390-398. [PubMed]

46. Mtshali, K.; Nakao, R.; Sugimoto, C.; Thekisoe, O. Occurrence of Coxiella burnetii, Ehrlichia canis, Rickettsia species and Anaplasma phagocytophilum-like bacterium in ticks collected from dogs and cats in South Africa. J. South Afr. Vet. Assoc. 2017, 88, 1-6. [CrossRef]

47. Mantovani, A.; Benazzi, P. The isolation of Coxiella burnetii from Rhipicephalus sanguineus on naturally infected dogs. J. Am. Vet. Med. Assoc. 1953, 122, 117-118. [PubMed]

48. Dantas-Torres, F. The brown dog tick, Rhipicephalus sanguineus (Latreille, 1806) (Acari: Ixodidae): From taxonomy to control. Vet. Parasitol. 2008, 152, 173-185. [CrossRef]

49. Selmi, R.; Mamlouk, A.; Ben Yahia, H.; Abdelaali, H.; Ben Said, M.; Sellami, K.; Daaloul-Jedidi, M.; Jemli, M.H.; Messadi, L. Coxiella burnetii in Tunisian dromedary camels (Camelus dromedarius): Seroprevalence, associated risk factors and seasonal dynamics. Acta Trop. 2018, 188, 234-239. [CrossRef]

50. Selmi, R.; Ben Said, M.; Mamlouk, A.; Ben Yahia, H.; Messadi, L. Molecular detection and genetic characterization of the potentially pathogenic Coxiella burnetii and the endosymbiotic Candidatus midichloria mitochondrii in ticks infesting camels (Camelus dromedarius) from Tunisia. Microb. Pathog. 2019, 136, 103655. [CrossRef]

51. Delaloye, J.; Pillonel, T.; Smaoui, M.; Znazen, A.; Abid, L.; Greub, G. Culture-independent genome sequencing of Coxiella burnetii from a native heart valve of a Tunisian patient with severe infective endocarditis. New Microbes New Infect. 2018, 21, 31-35. [CrossRef]

52. Duron, O.; Jourdain, E.; McCoy, K.D. Diversity and global distribution of the Coxiella intracellular bacterium in seabird ticks. Ticks Tick Borne Dis. 2014, 5, 557-563. [CrossRef] [PubMed] 
53. Buysse, M.; Plantard, O.; McCoy, K.D.; Duron, O.; Menard, C. Tissue localization of Coxiella-like endosymbionts in three European tick species through fluorescence in situ hybridization. Ticks Tick Borne Dis. 2019, 10, 798-804. [CrossRef] [PubMed]

54. Duron, O.; Sidi-Boumedine, K.; Rousset, E.; Moutailler, S.; Jourdain, E. The importance of ticks in Q fever transmission: What has (and has not) been demonstrated? Trends Parasitol. 2015, 31, 536-552. [CrossRef]

55. Chen, M.; Fan, M.Y.; Bi, D.Z. A molecular epidemiologic investigation of north Asia fever in scenic spots of Beijing suburb. Zhonghua Liu Xing Bing Xue Za Zhi 1997, 18, 197-200.

56. Orkun, Ö.; Çakmak, A.; Nalbantoğlu, S.; Karaer, Z. Molecular detection of a novel Babesia Sp. and pathogenic spotted fever group rickettsiae in ticks collected from hedgehogs in Turkey: Haemaphysalis erinacei, a novel candidate vector for the genus Babesia. Infect. Genet. Evol. 2019, 69, 190-198. [CrossRef]

57. Guo, L.P.; Mu, L.M.; Xu, J.; Jiang, S.H.; Wang, A.D.; Chen, C.F.; Guo, G.; Zhang, W.J.; Wang, Y.Z. Rickettsia raoultii in Haemaphysalis erinacei from marbled polecats, China-Kazakhstan border. Parasit. Vectors 2015, 8, 461. [CrossRef] [PubMed]

58. Hoogstraal, H. Notes on African Haemaphysalis ticks. I. The Mediterraneanlittoral hedgegog parasite H. erinacei Pavesi, 1884 (Ixodoidea, Ixodidae). J. Parasitol. 1955, 41, 221-233. [CrossRef]

59. Bursali, A.; Keskin, A.; Tekin, S. A review of the ticks (Acari: Ixodida) of Turkey: Species diversity, hosts and geographical distribution. Exp. Appl. Acarol. 2012, 57, 91-104. [CrossRef] [PubMed]

60. Znazen, A.; Khrouf, F.; Elleuch, N.; Lahiani, D.; Marrekchi, C.; M'Ghirbi, Y.; Ben Jemaa, M.; Bouattour, A.; Hammami, A. Multispacer typing of Rickettsia isolates from humans and ticks in Tunisia revealing new genotypes. Parasit. Vectors 2013, 6, 367. [CrossRef]

61. Khrouf, F.; M'Ghirbi, Y.; Znazen, A.; Ben Jemaa, M.; Hammami, A.; Bouattour, A. Detection of Rickettsia in Rhipicephalus sanguineus ticks and Ctenocephalides felis fleas from southeastern Tunisia by reverse line blot assay. J. Clin. Microbiol. 2014, 52, 268-274. [CrossRef]

62. Marié, J.L.; Davoust, B.; Socolovschi, C.; Raoult, D.; Parola, P. Molecular detection of rickettsial agents in ticks and fleas collected from a European hedgehog (Erinaceus europaeus) in Marseilles, France. Comp. Immunol. Microbiol. Infect. Dis. 2012, 35, 77-79. [CrossRef]

63. Marié, J.L.; Davoust, B.; Socolovschi, C.; Mediannikov, O.; Roqueplo, C.; Beaucournu, J.C.; Raoult, D.; Parola, P. Rickettsiae in arthropods collected from red foxes (Vulpes Vulpes) in France. Comp. Immunol. Microbiol. Infect. Dis. 2012, 35, 59-62. [CrossRef] [PubMed]

64. Fernández de Mera, I.G.; Zivkovic, Z.; Bolaños, M.; Carranza, C.; Pérez-Arellano, J.L.; Gutiérrez, C.; de la Fuente, J. Rickettsia massiliae in the Canary Islands. Emerg. Infect. Dis. 2009, 15, 1869-1870. [CrossRef]

65. Toledo, Á.; Olmeda, A.S.; Escudero, R.; Jado, I.; Valcárcel, F.; Casado-Nistal, M.A.; Rodríguez-Vargas, M.; Gil, H.; Anda, P. Tick-borne zoonotic bacteria in ticks collected from Central Spain. Am. J. Trop. Med. Hyg. 2009, 81, 67-74. [CrossRef] [PubMed]

66. Socolovschi, C.; Reynaud, P.; Kernif, T.; Raoult, D.; Parola, P. Rickettsiae of spotted fever group, Borrelia valaisiana, and Coxiella burnetii in ticks on passerine birds and mammals from the Camargue in the South of France. Ticks Tick Borne Dis. 2012, 3, 355-360. [CrossRef]

67. García-García, J.C.; Portillo, A.; Núñez, M.J.; Santibáñez, S.; Castro, B.; Oteo, J.A. A patient from Argentina infected with Rickettsia massiliae. Am. J. Trop. Med. Hyg. 2010, 82, 691-692. [CrossRef] [PubMed]

68. Cascio, A.; Torina, A.; Valenzise, M.; Blanda, V.; Camarda, N.; Bombaci, S.; Iaria, C.; De Luca, F.; Wasniewska, M. Scalp eschar and neck lymphadenopathy caused by Rickettsia massiliae. Emerg. Infect. Dis. 2013, 19, 836-837. [CrossRef]

69. Zaharia, M.; Popescu, C.P.; Florescu, S.A.; Ceausu, E.; Raoult, D.; Parola, P.; Socolovschi, C. Rickettsia massiliae infection and SENLAT syndrome in Romania. Ticks Tick Borne Dis. 2016, 7, 759-762. [CrossRef]

70. Vitale, G.; Mansueto, S.; Rolain, J.-M.; Raoult, D. Rickettsia massiliae human isolation. Emerg. Infect. Dis. 2006, 12, 174-175. [CrossRef]

71. Fedele, K.; Poh, K.C.; Brown, J.E.; Jones, A.; Durden, L.A.; Tiffin, H.S.; Pagac, A.; Li, A.Y.; Machtinger, E.T. Host distribution and pathogen infection of fleas (Siphonaptera) recovered from small mammals in Pennsylvania. J. Vector Ecol. 2020, 45, 32-44. [CrossRef]

72. Torina, A.; Blanda, V.; Antoci, F.; Scimeca, S.; D’Agostino, R.; Scariano, E.; Piazza, A.; Galluzzo, P.; Giudice, E.; Caracappa, S. A Molecular survey of Anaplasma Spp., Rickettsia Spp., Ehrlichia canis and Babesia microti in foxes and fleas from Sicily. Transbound Emerg Dis. 2013, 60, 125-130. [CrossRef]

73. Lindsay, L.R.; Barker, I.K.; Surgeoner, G.A.; McEwen, S.A.; Elliott, L.A.; Kolar, J. Apparent incompetence of Dermacentor variabilis (Acari: Ixodidae) and fleas (Insecta: Siphonaptera) as vectors of Borrelia burgdorferi in an Ixodes dammini endemic area of Ontario, Canada. J. Med. Entomol. 1991, 28, 750-753. [CrossRef] [PubMed]

74. Netušil, J.; Žákovská, A.; Vostal, K.; Norek, A.; Stanko, M. The occurrence of Borrelia burgdorferi Sensu Lato in certain ectoparasites (Mesostigmata, Siphonaptera) of Apodemus flavicollis and Myodes glareolus in chosen localities in the Czech Republic. Acta Parasit. 2013, 58, 337-341. [CrossRef] [PubMed]

75. Gern, L.; Rais, O. Efficient transmission of Borrelia burgdorferi between cofeeding Ixodes ricinus ticks (Acari: Ixodidae). J. Med. Entomol. 1996, 33, 189-192. [CrossRef] [PubMed]

76. Patrican, L.A. Acquisition of Lyme disease spirochetes by cofeeding Ixodes scapularis ticks. Am. J. Trop. Med. Hyg. 1997, 57, 589-593. [CrossRef] 
77. Belli, A.; Sarr, A.; Rais, O.; Rego, R.O.M.; Voordouw, M.J. Ticks infected via co-feeding transmission can transmit Lyme borreliosis to vertebrate hosts. Sci. Rep. 2017, 7, 5006. [CrossRef]

78. Brown, L.D.; Christofferson, R.C.; Banajee, K.H.; Del Piero, F.; Foil, L.D.; Macaluso, K.R. Cofeeding intra- and interspecific transmission of an Eemerging Insect-Borne Rickettsial Pathogen. Mol. Ecol. 2015, 24, 5475-5489. [CrossRef]

79. Milhano, N.; Palma, M.; Marcili, A.; Núncio, M.S.; de Carvalho, I.L.; de Sousa, R. Rickettsia lusitaniae sp. Nov. Isolated from the soft tick Ornithodoros erraticus (Acarina: Argasidae). Comp. Immunol. Microbiol. Infect. Dis. 2014, 37, 189-193. [CrossRef]

80. Sánchez-Montes, S.; Guzmán-Cornejo, C.; Martínez-Nájera, Y.; Becker, I.; Venzal, J.M.; Labruna, M.B. Rickettsia lusitaniae associated with Ornithodoros yumatensis (Acari: Argasidae) from two caves in Yucatan, Mexico. Ticks Tick Borne Dis. 2016, 7, 1097-1101. [CrossRef] [PubMed]

81. Zhao, S.; Yang, M.; Liu, G.; Hornok, S.; Zhao, S.; Sang, C.; Tan, W.; Wang, Y. Rickettsiae in the common pipistrelle Pipistrellus Pipistrellus (Chiroptera: Vespertilionidae) and the bat soft tick Argas vespertilionis (Ixodida: Argasidae). Parasit. Vectors 2020, 13, 10. [CrossRef]

82. Hornok, S.; Szőke, K.; Meli, M.L.; Sándor, A.D.; Görföl, T.; Estók, P.; Wang, Y.; Tu, V.T.; Kováts, D.; Boldogh, S.A.; et al. Molecular detection of vector-borne bacteria in bat ticks (Acari: Ixodidae, Argasidae) from eight countries of the old and new worlds. Parasit. Vectors 2019, 12. [CrossRef]

83. Bouattour, A.; Garnier, M.; M'Ghirbi, Y.; Sarih, M.; Gern, L.; Ferquel, E.; Postic, D.; Cornet, M. Borrelia crocidurae infection of Ornithodoros erraticus (Lucas, 1849) ticks in Tunisia. Vector Borne Zoonotic Dis. 2010, 10, 825-830. [CrossRef] [PubMed]

84. Gilles, J.; Silaghi, C.; Just, F.T.; Pradel, I.; Pfister, K. Polymerase chain reaction detection of Rickettsia felis-like organism in Archaeopsylla erinacei (Siphonaptera: Pulicidae) from Bavaria, Germany. J. Med. Entomol. 2009, 46, 703-707. [CrossRef] [PubMed]

85. Barradas, P.F.; Mesquita, J.R.; Mateus, T.L.; Ferreira, P.; Amorim, I.; Gärtner, F.; de Sousa, R. Molecular detection of Rickettsia Spp. in ticks and fleas collected from rescued hedgehogs (Erinaceus europaeus) in Portugal. Exp. Appl. Acarol. 2021, 83, 449-460. [CrossRef] [PubMed]

86. De Sousa, R.; Edouard-Fournier, P.; Santos-Silva, M.; Amaro, F.; Bacellar, F.; Raoult, D. Molecular detection of Rickettsia felis, Rickettsia typhi and two genotypes closely related to Bartonella elizabethae. Am. J. Trop. Med. Hyg. 2006, 75, 727-731. [CrossRef]

87. Gilles, J.; Just, F.T.; Silaghi, C.; Pradel, I.; Passos, L.M.F.; Lengauer, H.; Hellmann, K.; Pfister, K. Rickettsia felis in Fleas, Germany. Emerg. Infect. Dis. 2008, 14, 1294-1296. [CrossRef]

88. Maina, A.N.; Jiang, J.; Luce-Fedrow, A.; St. John, H.K.; Farris, C.M.; Richards, A.L. Worldwide presence and features of flea-borne Rickettsia asembonensis. Front. Vet. Sci. 2019, 5, 334. [CrossRef]

89. Maina, A.N.; Luce-Fedrow, A.; Omulo, S.; Hang, J.; Chan, T.-C.; Ade, F.; Jima, D.D.; Ogola, E.; Ge, H.; Breiman, R.F.; et al. Isolation and characterization of a novel Rickettsia species (Rickettsia asembonensis sp. Nov.) obtained from cat fleas (Ctenocephalides felis). Int. J. Syst. Evol. Microbiol. 2016, 66, 4512-4517. [CrossRef]

90. Eremeeva, M.E.; Capps, D.; McBride, C.L.; Williams-Newkirk, A.J.; Dasch, G.A.; Salzer, J.S.; Beati, L.; Durden, L.A. Detection of Rickettsia asembonensis in fleas (Siphonaptera: Pulicidae, Ceratophyllidae) collected in five counties in Georgia, United States. J. Med. Entomol. 2020, 57, 1246-1253. [CrossRef]

91. Silva, A.B.; Vizzoni, V.F.; Costa, A.P.; Costa, F.B.; Moraes-Filho, J.; Labruna, M.B.; Gazêta, G.S.; de Maria Seabra Nogueira, R. First report of a Rickettsia asembonensis related infecting fleas in Brazil. Acta Trop. 2017, 172, 44-49. [CrossRef]

92. Colonia, C.B.; Ramírez-Hernández, A.; Gil-Mora, J.; Agudelo, J.C.; Villa, G.J.C.; Pino, C.; Betancourt-Ruiz, P.; Cárdenas, J.E.P.; Blanton, L.S.; Hidalgo, M. Flea-borne Rickettsia species in fleas, Caldas Department, Colombia. J. Infect. Dev. Ctries. 2020, 14, 1155-1163. [CrossRef]

93. Nziza, J.; Tumushime, J.C.; Cranfield, M.; Ntwari, A.E.; Modrý, D.; Mudakikwa, A.; Gilardi, K.; Šlapeta, J. Fleas from domestic dogs and rodents in Rwanda Carry Rickettsia asembonensis and Bartonella tribocorum. Med. Vet. Entomol. 2019, 33, 177-184. [CrossRef] [PubMed]

94. Nataraj, N.; Muthuraman, K.; Sundaram, D.; Ayyanar, E.; Ashokkumar, M.; Kasinathan, G.; Devaraju, P. Molecular detection of Candidatus Rickettsia asembonensis in fleas collected from pets and domestic animals in Puducherry, India. Med. Vet. Entomol. 2020, 34, 498-502. [CrossRef]

95. Moonga, L.C.; Hayashida, K.; Nakao, R.; Lisulo, M.; Kaneko, C.; Nakamura, I.; Eshita, Y.; Mweene, A.S.; Namangala, B.; Sugimoto, C.; et al. Molecular detection of Rickettsia felis in dogs, rodents and cat fleas in Zambia. Parasit. Vectors 2019, 12, 168. [CrossRef] [PubMed]

96. Sánchez-Montes, S.; Salceda-Sánchez, B.; Ballados-González, G.G.; Valtierra-Alzaga, L.; Soto-Gutiérrez, J.J.; Becker, I. Rickettsia asembonensis: New records associated with the cat flea (Ctenocephalides felis felis) in Mexico. Vet. Parasitol. Reg. Stud. Rep. 2020, 21, 100433. [CrossRef]

97. Otiang, E.; Chen, D.; Jiang, J.; Maina, A.N.; Farris, C.M.; Luce-Fedrow, A.; Richards, A.L. Pathogen carriage by peri-domestic fleas in Western Kenya. Vector Borne Zoonotic Dis. 2021, 21, 256-263. [CrossRef] [PubMed]

98. Ferreira, F.C.; Fonseca, D.M.; Hamilton, G.; Price, D. Metagenomic analysis of human-biting cat fleas in urban northeastern United States of America reveals an emerging zoonotic pathogen. Sci. Rep. 2020, 10, 1-8. [CrossRef]

99. Dall'Agnol, B.; Souza, U.; Webster, A.; Weck, B.; Stenzel, B.; Labruna, M.; Klafke, G.; Martins, J.R.; Ferreira, C.A.S.; Reck, J. "Candidatus Rickettsia asemboensis" in Rhipicephalus sanguineus ticks, Brazil. Acta Trop. 2017, 167, 18-20. [CrossRef] 
100. Low, V.L.; Prakash, B.K.; Tan, T.K.; Sofian-Azirun, M.; Anwar, F.H.K.; Vinnie-Siow, W.Y.; AbuBakar, S. Pathogens in ectoparasites from free-ranging animals: Infection with Rickettsia asembonensis in ticks, and a potentially new species of Dipylidium in fleas and lice. Vet. Parasitol. 2017, 245, 102-105. [CrossRef]

101. Tay, S.T.; Koh, F.X.; Kho, K.L.; Sitam, F.T. Rickettsial infections in Monkeys, Malaysia. Emerg. Infect. Dis. 2015, $21,545-547$. [CrossRef]

102. Phoosangwalthong, P.; Hii, S.F.; Kamyingkird, K.; Kengradomkij, C.; Pinyopanuwat, N.; Chimnoi, W.; Traub, R.J.; Inpankaew, T. Cats as potential mammalian reservoirs for Rickettsia sp. genotype RF2125 in Bangkok, Thailand. Vet. Parasitol. Reg. Stud. Rep. 2018, 13, 188-192. [CrossRef]

103. Pomykal, J. A Case of infestation of humans with fleas Archaeopsylla erinacei (Siphonaptera, Pulicidae). Folia Parasitol. 1985, 32,348 .

104. Greigert, V.; Brunet, J.; Ouarti, B.; Laroche, M.; Pfaff, A.W.; Henon, N.; Lemoine, J.-P.; Mathieu, B.; Parola, P.; Candolfi, E.; et al. The trick of the hedgehog: Case report and short review about Archaeopsylla erinacei (Siphonaptera: Pulicidae) in human health. J. Med. Entomol. 2020, 57, 318-323. [CrossRef] [PubMed]

105. Palacios-Salvatierra, R.; Cáceres-Rey, O.; Vásquez-Domínguez, A.; Mosquera-Visaloth, P.; Anaya-Ramírez, E. Rickettsial species in human cases with non-specific acute febrile syndrome in Peru. Rev. Peru. Med. Exp. Salud Publica 2018, 35, 630-635. [CrossRef] [PubMed]

106. Kho, K.L.; Koh, F.X.; Singh, H.K.L.; Zan, H.A.M.; Kukreja, A.; Ponnampalavanar, S.; Tay, S.T. Spotted fever group rickettsioses and murine typhus in a Malaysian teaching hospital. Am. J. Trop. Med. Hyg. 2016, 95, 765-768. [CrossRef] [PubMed]

107. Fang, L.-Z.; Lei, S.-C.; Yan, Z.-J.; Xiao, X.; Liu, J.-W.; Gong, X.-Q.; Yu, H.; Yu, X.-J. Detection of multiple intracellular bacterial pathogens in Haemaphysalis Flava ticks collected from hedgehogs in Central China. Pathogens 2021, 10, 115. [CrossRef] [PubMed]

108. Sarih, M.; M'Ghirbi, Y.; Bouattour, A.; Gern, L.; Baranton, G.; Postic, D. Detection and identification of Ehrlichia spp. in ticks collected in Tunisia and Morocco. J. Clin. Microbiol. 2005, 43, 1127-1132. [CrossRef]

109. Kawahara, M.; Rikihisa, Y.; Lin, Q.; Isogai, E.; Tahara, K.; Itagaki, A.; Hiramitsu, Y.; Tajima, T. Novel genetic variants of Anaplasma phagocytophilum, Anaplasma bovis, Anaplasma centrale, and a novel Ehrlichia sp. in wild deer and ticks on two major islands in Japan. Appl. Environ. Microbiol. 2006, 72, 1102-1109. [CrossRef]

110. Koh, F.X.; Kho, K.L.; Kisomi, M.G.; Wong, L.P.; Bulgiba, A.; Tan, P.E.; Lim, Y.A.L.; Nizam, Q.N.H.; Panchadcharam, C.; Tay, S.T. Ehrlichia and Anaplasma infections: Serological evidence and tick surveillance in Peninsular Malaysia. J. Med. Entomol. 2018, 55, 269-276. [CrossRef] [PubMed]

111. Matsumoto, K.; Takeuchi, T.; Yokoyama, N.; Katagiri, Y.; Ooshiro, M.; Zakimi, S.; Gaowa, N.; Kawamori, F.; Ohashi, N.; Inokuma, $\mathrm{H}$. Detection of the new Ehrlichia species closely related to Ehrlichia ewingii from Haemaphysalis longicornis in Yonaguni Island, Okinawa, Japan. J. Vet. Med. Sci. 2011, 73, 1485-1488. [CrossRef]

112. Mohammed, O.B.; Amor, N.M.S.; Omer, S.A.; Alagaili, A.N. Molecular detection and characterization of Theileria sp. from hedgehogs (Paraechinus aethiopicus) in Saudi Arabia. Lett. Appl. Microbiol. 2021, 74, 476-483. [CrossRef]

113. Chen, Z.; Liu, Q.; Jiao, F.-C.; Xu, B.-L.; Zhou, X.-N. Detection of piroplasms infection in sheep, dogs and hedgehogs in Central China. Infect. Dis. Poverty 2014, 3, 18. [CrossRef]

114. Al-Fahdi, A.; Alqamashoui, B.; Al-Hamidhi, S.; Kose, O.; Tageldin, M.H.; Bobade, P.; Johnson, E.H.; Hussain, A.-R.; Karagenc, T.; Tait, A.; et al. Molecular surveillance of Theileria parasites of livestock in Oman. Ticks Tick Borne Dis. 2017, 8, 741-748. [CrossRef] [PubMed]

115. Bishop, R.; Musoke, A.; Morzaria, S.; Gardner, M.; Nene, V. Theileria: Intracellular protozoan parasites of wild and domestic ruminants transmitted by ixodid ticks. Parasitology 2004, 129, S271-S283. [CrossRef]

116. Hao, L.; Yuan, D.; Li, S.; Jia, T.; Guo, L.; Hou, W.; Lu, Z.; Mo, X.; Yin, J.; Yang, A.; et al. Detection of Theileria spp. in ticks, sheep keds (Melophagus ovinus), and livestock in the Eastern Tibetan Plateau, China. Parasitol. Res. 2020, 119, 2641-2648. [CrossRef] [PubMed]

117. King'ori, E.; Obanda, V.; Chiyo, P.I.; Soriguer, R.C.; Morrondo, P.; Angelone, S. Molecular identification of Ehrlichia, Anaplasma, Babesia and Theileria in African elephants and their ticks. PLoS ONE 2019, 14, e0226083. [CrossRef] [PubMed]

118. Li, Y.; Li, X.; Liu, J.; Wang, J.; Jia, D.; Liu, A.; He, Z.; Guan, G.; Liu, Z.; Liu, G.; et al. First report of Theileria infection of bactrian camels (Camelus bactrianus) in Xinjiang, China. Acta Parasitol. 2019, 64, 923-926. [CrossRef] [PubMed]

119. Rjeibi, M.R.; Amairia, S.; Rouatbi, M.; Ben Salem, F.; Mabrouk, M.; Gharbi, M. Molecular prevalence and genetic characterization of piroplasms in dogs from Tunisia. Parasitology 2016, 143, 1622-1628. [CrossRef]

120. M'ghirbi, Y.; Ros-García, A.; Iribar, P.; Rhaim, A.; Hurtado, A.; Bouattour, A.A. Molecular study of tick-borne haemoprotozoan parasites (Theileria and Babesia) in small ruminants in northern Tunisia. Vet. Parasitol. 2013, 198, 72-77. [CrossRef]

121. Ros-García, A.; M'ghirbi, Y.; Hurtado, A.; Bouattour, A. Prevalence and genetic diversity of piroplasm species in horses and ticks from Tunisia. Infect. Genet. Evol. 2013, 17, 33-37. [CrossRef]

122. de Sousa, K.C.M.; Fernandes, M.P.; Herrera, H.M.; Benevenute, J.L.; Santos, F.M.; Rocha, F.L.; Barreto, W.T.G.; Macedo, G.C.; Campos, J.B.; Martins, T.F.; et al. Molecular detection of Hepatozoon spp. in domestic dogs and wild mammals in Southern Pantanal, Brazil with implications in the transmission route. Vet. Parasitol. 2017, 237, 37-46. [CrossRef]

123. Dezdek, D.; Vojta, L.; Curković, S.; Lipej, Z.; Mihaljević, Z.; Cvetnić, Z.; Beck, R. Molecular detection of Theileria annae and Hepatozoon canis in foxes (Vulpes vulpes) in Croatia. Vet. Parasitol. 2010, 172, 333-336. [CrossRef] 
124. Modrý, D.; Beck, R.; Hrazdilová, K.; Baneth, G. A Review of methods for detection of Hepatozoon infection in carnivores and arthropod vectors. Vector Borne Zoonotic Dis. 2017, 17, 66-72. [CrossRef]

125. Morelli, S.; Diakou, A.; Traversa, D.; Di Gennaro, E.; Simonato, G.; Colombo, M.; Dimzas, D.; Grillini, M.; Frangipane di Regalbono, A.; Beugnet, F.; et al. First record of Hepatozoon Spp. in domestic cats in Greece. Ticks Tick Borne Dis. 2021, $12,101580$. [CrossRef]

126. Bouattour, A.; Chabchoub, A.; Hajjaji, I.; M'ghirbi, Y. Hepatozoon canis and Babesia vogeli infections of dogs in Tunisia. Vet. Parasitol. Reg. Stud. Rep. 2021, 23, 100512. [CrossRef]

127. Yang, J.; Liu, Z.; Niu, Q.; Liu, J.; Xie, J.; Chen, Q.; Chen, Z.; Guan, G.; Liu, G.; Luo, J.; et al. Evaluation of different nested PCRs for detection of Anaplasma phagocytophilum in ruminants and ticks. BMC Vet. Res. 2016, 12, 35. [CrossRef]

128. Santos, A.S.; Santos-Silva, M.M.; de Sousa, R.; Bacellar, F.; Dumler, J.S. PCR-based survey of Anaplasma phagocytophilum in portuguese ticks (Acari: Ixodidae). Vector Borne Zoonotic Dis. 2009, 9, 33-40. [CrossRef]

129. Kang, Y.-J.; Diao, X.-N.; Zhao, G.-Y.; Chen, M.-H.; Xiong, Y.; Shi, M.; Fu, W.-M.; Guo, Y.-J.; Pan, B.; Chen, X.-P.; et al. Extensive diversity of rickettsiales bacteria in two species of ticks from China and the evolution of the rickettsiales. BMC Evol. Biol. 2014, 14, 167. [CrossRef]

130. Guo, W.-P.; Tian, J.-H.; Lin, X.-D.; Ni, X.-B.; Chen, X.-P.; Liao, Y.; Yang, S.-Y.; Dumler, J.S.; Holmes, E.C.; Zhang, Y.-Z. Extensive genetic diversity of rickettsiales bacteria in multiple mosquito species. Sci. Rep. 2016, 6, 38770. [CrossRef]

131. M'ghirbi, Y.; Bèji, M.; Oporto, B.; Khrouf, F.; Hurtado, A.; Bouattour, A. Anaplasma marginale and A. phagocytophilum in Cattle in Tunisia. Parasit. Vectors 2016, 9, 556. [CrossRef]

132. Jahfari, S.; Ruyts, S.C.; Frazer-Mendelewska, E.; Jaarsma, R.; Verheyen, K.; Sprong, H. Melting pot of tick-borne zoonoses: The European hedgehog contributes to the maintenance of various tick-borne diseases in natural cycles urban and suburban areas. Parasit. Vectors 2017, 10, 134. [CrossRef]

133. Khodadadi, N.; Nabavi, R.; Sarani, A.; Saadati, D.; Ganjali, M.; Mihalca, A.D.; Otranto, D.; Sazmand, A. Identification of Anaplasma marginale in long-eared hedgehogs (Hemiechinus auritus) and their Rhipicephalus turanicus ticks in Iran. Ticks Tick Borne Dis. 2021, 12, 101641. [CrossRef] [PubMed]

134. Naddaf, S.R.; Mahmoudi, A.; Ghasemi, A.; Rohani, M.; Mohammadi, A.; Ziapour, S.P.; Nemati, A.H.; Mostafavi, E. Infection of hard ticks in the Caspian Sea littoral of Iran with Lyme borreliosis and relapsing fever borreliae. Ticks Tick Borne Dis. 2020, 11, 101500. [CrossRef] [PubMed]

135. McCoy, B.N.; Maïga, O.; Schwan, T.G. Detection of Borrelia theileri in Rhipicephalus geigyi from Mali. Ticks Tick Borne Dis. 2014, 5, 401-403. [CrossRef] [PubMed]

136. Mitchell, E.A.; Williamson, P.C.; Billingsley, P.M.; Seals, J.P.; Ferguson, E.E.; Allen, M.S. Frequency and distribution of rickettsiae, borreliae, and ehrlichiae detected in human-parasitizing ticks, Texas, USA. Emerg. Infect. Dis. 2016, 22, 312-315. [CrossRef]

137. Majerová, K.; Hönig, V.; Houda, M.; Papežík, P.; Fonville, M.; Sprong, H.; Rudenko, N.; Golovchenko, M.; Černá Bolfíková, B.; Hulva, P.; et al. Hedgehogs, squirrels, and blackbirds as sentinel hosts for active surveillance of Borrelia miyamotoi and Borrelia burgdorferi complex in urban and rural environments. Microorganisms 2020, 8, 1908. [CrossRef]

138. Skuballa, J.; Petney, T.; Pfäffle, M.; Oehme, R.; Hartelt, K.; Fingerle, V.; Kimmig, P.; Taraschewski, H. Occurrence of different Borrelia burgdorferi Sensu Lato genospecies including, B. Afzelii, B. Bavariensis, and B. Spielmanii in Hedgehogs (Erinaceus spp.) in Europe. Ticks Tick Borne Dis. 2012, 3, 8-13. [CrossRef] [PubMed]

139. Ben Said, M.; Belkahia, H.; Alberti, A.; Abdi, K.; Zhioua, M.; Daaloul-Jedidi, M.; Messadi, L. First molecular evidence of Borrelia burgdorferi Sensu Lato in goats, sheep, cattle and camels in Tunisia. Ann. Agric. Environ. Med. 2016, 23, 442-447. [CrossRef] [PubMed]

140. Younsi, H.; Sarih, M.; Jouda, F.; Godfroid, E.; Gern, L.; Bouattour, A.; Baranton, G.; Postic, D. Characterization of Borrelia lusitaniae isolates collected in Tunisia and Morocco. J. Clin. Microbiol. 2005, 43, 1587-1593. [CrossRef] [PubMed]

141. Zouari, S.; Khrouf, F.; M'ghirbi, Y.; Bouattour, A. First molecular detection and characterization of zoonotic Bartonella species in fleas infesting domestic animals in Tunisia. Parasit. Vectors 2017, 10. [CrossRef]

142. Belkhiria, J.; Chomel, B.B.; Ben Hamida, T.; Kasten, R.W.; Stuckey, M.J.; Fleischman, D.A.; Christopher, M.M.; Boulouis, H.-J.; Farver, T.B. Prevalence and potential risk factors for Bartonella infection in Tunisian stray dogs. Vector Borne Zoonotic Dis. 2017, 17, 388-397. [CrossRef]

143. Znazen, A.; Rolain, J.-M.; Hammami, N.; Kammoun, S.; Hammami, A.; Raoult, D. High prevalence of Bartonella quintana endocarditis in Sfax, Tunisia. Am. J. Trop. Med. Hyg. 2005, 72, 503-507. [CrossRef]

144. Selmi, R.; Ben Said, M.; Ben Yahia, H.; Abdelaali, H.; Boulouis, H.-J.; Messadi, L. First report on Bartonella henselae in dromedary camels (Camelus Dromedarius). Infect. Genet. Evol. 2020, 85, 104496. [CrossRef]

145. Bitam, I.; Rolain, J.M.; Nicolas, V.; Tsai, Y.-L.; Parola, P.; Gundi, V.A.K.B.; Chomel, B.B.; Raoult, D. A Multi-gene analysis of diversity of Bartonella detected in fleas from Algeria. Comp. Immunol. Microbiol. Infect. Dis. 2012, 35, 71-76. [CrossRef] [PubMed]

146. Hornok, S.; Földvári, G.; Rigó, K.; Meli, M.L.; Tóth, M.; Molnár, V.; Gönczi, E.; Farkas, R.; Hofmann-Lehmann, R. Vector-borne agents detected in fleas of the northern white-breasted hedgehog. Vector Borne Zoonotic Dis. 2014, 14, 74-76. [CrossRef]

147. Sacristán, C.; das Neves, C.G.; Suhel, F.; Sacristán, I.; Tengs, T.; Hamnes, I.S.; Madslien, K. Bartonella Spp. Detection in ticks, culicoides biting midges and wild cervids from Norway. Transbound Emerg. Dis. 2020. [CrossRef] 
148. de Sousa, K.C.M.; do Amaral, R.B.; Herrera, H.M.; Santos, F.M.; Macedo, G.C.; de Andrade Pinto, P.C.E.; Barros-Battesti, D.M.; Machado, R.Z.; André, M.R. Genetic diversity of Bartonella Spp. in wild mammals and ectoparasites in Brazilian Pantanal. Microb. Ecol. 2018, 76, 544-554. [CrossRef] [PubMed]

149. López-Pérez, A.M.; Osikowicz, L.; Bai, Y.; Montenieri, J.; Rubio, A.; Moreno, K.; Gage, K.; Suzán, G.; Kosoy, M. Prevalence and phylogenetic analysis of Bartonella species of wild carnivores and their fleas in northwestern Mexico. Ecohealth 2017, 14, 116-129. [CrossRef]

150. Yin, X.; Zhao, S.; Yan, B.; Tian, Y.; Ba, T.; Zhang, J.; Wang, Y. Bartonella rochalimae, B. grahamii, B. elizabethae, and Wolbachia spp. in fleas from wild rodents near the China-Kazakhstan border. Korean J. Parasitol. 2019, 57, 553-559. [CrossRef]

151. Ehlers, J.; Krüger, A.; Rakotondranary, S.J.; Ratovonamana, R.Y.; Poppert, S.; Ganzhorn, J.U.; Tappe, D. Molecular detection of Rickettsia spp., Borrelia spp., Bartonella spp. and Yersinia pestis in ectoparasites of endemic and domestic animals in southwest Madagascar. Acta Trop. 2020, 205, 105339. [CrossRef]

152. Panthawong, A.; Grieco, J.P.; Ngoen-Klan, R.; Chao, C.-C.; Chareonviriyaphap, T. Detection of Anaplasma spp. and Bartonella spp. from wild-caught rodents and their ectoparasites in Nakhon Ratchasima Province, Thailand. J. Vector Ecol. 2020, 45, $241-253$. [CrossRef]

153. Bouattour, A. Dichotomous identification keys of ticks (Acari: Ixodidae), livestock parasites in North Africa. Arch. Inst. Pasteur Tunis 2002, 79, 43-50.

154. Beaucournu, J.C. Ajouts et corrections à la faune des Puces de France et du Bassin méditerranéen occidental (Siphonaptera). Bull. Soc. Entomol. Fr. 2013, 118, 173-196.

155. Michelet, L.; Delannoy, S.; Devillers, E.; Umhang, G.; Aspan, A.; Juremalm, M.; Chirico, J.; van der Wal, F.J; Sprong, H.; Boye Pihl, T.P.; et al. High-throughput screening of tick-borne pathogens in Europe. Front. Cell. Infect. Microbiol. 2014, 4, 103. [CrossRef]

156. Nielsen, E.M.; Andersen, M.T. Detection and characterization of verocytotoxin-producing Escherichia coli by automated $5^{\prime}$ nuclease PCR assay. J. Clin. Microbiol. 2003, 41, 2884-2893. [CrossRef]

157. Regnery, R.L.; Spruill, C.L.; Plikaytis, B.D. Genotypic identification of rickettsiae and estimation of intraspecies sequence divergence for portions of two rickettsial genes. J. Bacteriol. 1991, 173, 1576-1589. [CrossRef]

158. Choi, Y.-J.; Lee, S.-H.; Park, K.-H.; Koh, Y.-S.; Lee, K.-H.; Baik, H.-S.; Choi, M.-S.; Kim, I.-S.; Jang, W.-J. Evaluation of PCR-based assay for diagnosis of spotted fever group rickettsiosis in human serum samples. Clin. Diagn. Lab. Immunol. 2005, 12, 759-763. [CrossRef]

159. Rar, V.A.; Fomenko, N.V.; Dobrotvorsky, A.K.; Livanova, N.N.; Rudakova, S.A.; Fedorov, E.G.; Astanin, V.B.; Morozova, O.V. Tickborne pathogen detection, western Siberia, Russia. Emerg. Infect. Dis. 2005, 11, 1708-1715. [CrossRef]

160. Inokuma, H.; Okuda, M.; Ohno, K.; Shimoda, K.; Onishi, T. Analysis of the $18 \mathrm{~S}$ rRNA gene sequence of a Hepatozoon detected in two Japanese dogs. Vet. Parasitol. 2002, 106, 265-271. [CrossRef]

161. Bonnet, S.; Jouglin, M.; L'Hostis, M.; Chauvin, A. Babesia sp. EU1 from roe deer and transmission within Ixodes ricinus. Emerg. Infect. Dis. 2007, 13, 1208-1210. [CrossRef]

162. Masatani, T.; Hayashi, K.; Andoh, M.; Tateno, M.; Endo, Y.; Asada, M.; Kusakisako, K.; Tanaka, T.; Gokuden, M.; Hozumi, N.; et al. Detection and molecular characterization of Babesia, Theileria, and Hepatozoon species in hard ticks collected from Kagoshima, the southern region in Japan. Ticks Tick Borne Dis. 2017, 8, 581-587. [CrossRef]

163. Loh, S.-M.; Gofton, A.W.; Lo, N.; Gillett, A.; Ryan, U.M.; Irwin, P.J.; Oskam, C.L. Novel Borrelia species detected in echidna ticks, Bothriocroton concolor, in Australia. Parasit. Vectors 2016, 9, 339. [CrossRef] [PubMed]

164. Norman, A.F.; Regnery, R.; Jameson, P.; Greene, C.; Krause, D.C. Differentiation of Bartonella-like isolates at the species level by PCR-restriction fragment length polymorphism in the citrate synthase gene. J. Clin. Microbiol. 1995, 33, 1797-1803. [CrossRef]

165. Edgar, R.C. MUSCLE: Multiple sequence alignment with high accuracy and high throughput. Nucleic Acids Res. 2004, 32, 1792-1797. [CrossRef]

166. Kumar, S.; Stecher, G.; Li, M.; Knyaz, C.; Tamura, K. MEGA X: Molecular evolutionary genetics analysis across computing platforms. Mol. Biol. Evol. 2018, 35, 1547-1549. [CrossRef] [PubMed]

167. Tamura, K.; Nei, M. Estimation of the number of nucleotide substitutions in the control region of mitochondrial DNA in humans and chimpanzees. Mol. Biol. Evol. 1993, 10, 512-526. [CrossRef] [PubMed] 